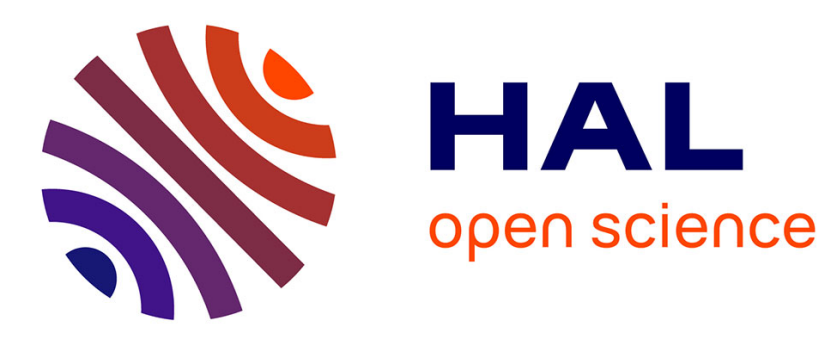

\title{
Heterogeneity matters: labour productivity differentiated by age and skills
}

\author{
Muriel Roger, Malgorzata Wasmer
}

\section{To cite this version:}

Muriel Roger, Malgorzata Wasmer. Heterogeneity matters: labour productivity differentiated by age and skills. 2009. halshs-00575086

\section{HAL Id: halshs-00575086 \\ https://shs.hal.science/halshs-00575086}

Preprint submitted on 9 Mar 2011

HAL is a multi-disciplinary open access archive for the deposit and dissemination of scientific research documents, whether they are published or not. The documents may come from teaching and research institutions in France or abroad, or from public or private research centers.
L'archive ouverte pluridisciplinaire HAL, est destinée au dépôt et à la diffusion de documents scientifiques de niveau recherche, publiés ou non, émanant des établissements d'enseignement et de recherche français ou étrangers, des laboratoires publics ou privés. 


\section{PARISSCHOOL OF ECQNOMICS}

WORKING PAPER № 2009 - 51

Heterogeneity matters: labour productivity

differentiated by age and skills

Muriel Roger

Malgorzata Wasmer

JEL Codes: J24, J31, J41

Keywords: Ageing, older workers, labour productivity, CES production function, endogeneity 


\title{
Heterogeneity matters: labour productivity differentiated by age and skills*
}

\author{
Muriel Roger ${ }^{\dagger}$
}

Malgorzata Wasmer ${ }^{\ddagger}$

\footnotetext{
${ }^{*}$ The data analysis has been completed during the research stay of Malgorzata Wasmer at the Institut National de la Statistique et des Etudes Economique in Paris. We would like to thank Didier Blanchet for his hospitality. We would also like to thank Sébastien Roux and Anthony Briant for their fruitful remarks as our work was progressing and to Virginie Régnier for her assistance in the dataset construction. Helpful comments were received from participants of the internal INSEE seminar, the $57^{\text {th }}$ Congress of AFSE (French Association of Economic Science), $26^{\text {th }}$ JMA (Journées de Microéconomie Appliquées), EEA-ESEM 2009 and EALE 2009.

${ }^{\dagger}$ D3E-INSEE and Paris School of Economics (INRA), 48 Bd Jourdan, 75014 Paris, France, e-mail: muriel.roger@ens.fr

${ }^{\ddagger}$ Corresponding author. University of Fribourg and Université Lumière Lyon 2, GATE/CNRS. Adresse: University of Fribourg, Economics Department, Bd de Pérolles 90, Office G 510, 1700 Fribourg, Switzerland, tel: $+41(0) 263008222$, e-mail: malgorzata.wasmer@unifr.ch
} 


\section{Introduction}

An ageing population bears important consequences for labour markets. Policy makers and an increasing number of individual organisations as well as private firms realise that early retirement of older employees deprives companies of valuable expertise and creates a shortage of qualified employees. Thus, the trend towards early retirement policies starts being reversed.

Nevertheless, the available evidence indicates that in many countries older workers continue to confront unfavourable labour market conditions compared to other age groups. Despite the increasing need for working life extension as well as the age diversity enabling the transmission of skills and know-how, the employment and hire rates of older workers stay at a very low level in many developed countries. Employers' negative perceptions about the adaptability and productivity of older employees are among the reasons. An increase in the workforce's average age is frequently associated with higher labour costs as well as greater resistance to technological developments and only rarely with an expected increase in productivity (Remery et al., 2003). Although employers appreciate older employees' experience, loyalty and low turnover, nevertheless younger workers are preferred when it comes to actual hiring decisions (Guest and Shacklock, 2005).

Actually, the distribution of productivity across the age groups is not a priori determined. It can be higher for older workers due to longer experience acquired and higher level of job specific knowledge. On the other hand, the older workers' efficiency might become deteriorated as a result of the structural changes in the labour market, e.g. accelerating technological progress and less training offered (Daveri and Maliranta, 2006; Maurer, 2001). Interestingly, age-productivity profile might differ between occupations. Older employees can remain highly productive in the domain that they know well and where relatively long experience is important. Thanks to tacit knowledge, older managers may perform as well as younger ones (ColoniaWillner, 1998). On the other hand, reduction in productivity of seniors appears to be the strongest in jobs where speed, spatial orientation and learning new materials are important (Skirbekk, 2003).

In particular, the situation of older workers on the labour market may be undermined when aging drives a negative wedge between the workers' productivity and earnings. The increasing age-earnings pattern characterised by lower wages for young workers and higher wages for older workers is widely observed (Loewenstein and Sicherman, 1991). This fact combined with doubts about the true productivity of older workers raises an important question on the relations between productivity and earnings across the age groups. There exists some empirical evidence against the paradigm of wage and marginal productivity equality. Frank (1984) as well as Campbell and Kamlani (1997) have found that wage rates vary substantially less than do individual productivity values. Even if a wide discrepancy in productivity among individual

workers exists, many firms continue to follow strict remuneration scheme based on 
education, experience and tenure length. As a result of rigid remuneration system, in response to a negative productivity shock, employers instead of adjusting wages, adjust their employment structure. Consequently, the least productive workers are the first to become redundant. Likewise, the employment opportunities of workers whose wages exceed their productivity levels become reduced.

The present study aims at evaluating the actual profile of marginal productivity across the age classes within the workforce. The comparison to profile of earnings let us analyse the relative productivity and test whether differences in wage shares across groups of workers are justified by proportional productivity contribution. Since, as mentioned above, age-productivity profile might differ between occupations, the workforce has been differentiated not only by age (young, middle-aged, old), but also by skills (low-skilled, high-skilled). The simultaneous differentiation by age and by skills is of high interest in the perspective of possible dissimilarities among different categories of workers with respect to the sensitivity to work effort incentives, training offered, etc.

Although there is a growing research interest in the relation between age and productivity, the empirical analyses so far have often been focused on the estimation of Cobb-Douglas production functions specification in capital and labour. The firmlevel labour productivity itself was treated as a simple summation of productivities of individual workers (Hellerstein et al., 1999; Crépon et al., 2002; Aubert and Crépon, 2003). Thus, the existing studies are characterised by a limitation of perfect substitutability between different categories of workers. In this study, we refer to the production function estimation as well. However, in contrast to the previous studies, the use of the less restrictive, constant-elasticity-of-substitution (CES) functional form is proposed at the level of labour input. This more general form, thanks to smaller number of constraints imposed on the production technology, allows the imperfect substitution between different categories of workers. The potential correlation between inputs and productivity has been controlled for according to the method by Levinsohn and Petrin (2003).

The dataset used in this study (DADS-BRN) covers the French manufacturing, services and trade sectors. French data are particularly interesting in the perspective of our study. Actually, among all OECD countries, France is characterised by the highest employment rate of people aged 25-54 (83\% in 2008) and at the same time one of the lowest employment rate of people over 55 (38\% in 2008). In fact, workers over 50 are often touched by long-term unemployment. In particular, the low-skilled workers face problems to stay employed and once unemployed, they hardly find a new job.

A differentiation of workforce simultaneously by age and skills let us observe the differences in the age-productivity and age-earnings profiles separately within each skill group. We find that this differentiation is, in fact, very important. The observed productivity profile across different age groups seems actually depending on the skill 
level. Among the main findings of this study, labour productivity is found to be the lowest for the oldest low-skilled workers. In the high-skilled labour category, in manufacturing, the mean productivity stays quite stable across the age groups, being the highest for the workers over 50. In trade, the high-skilled oldest employees are clearly the most productive group. As far as age-earnings pattern is concerned, we observe a very similar pattern throughout the sectors. The wage rates vary considerably less than productivity in both skill groups. The wage profile is however steeper for the high-skilled workers.

The results for manufacturing sector show that the age-productivity and age-earnings profiles are compatible with a deferred compensation system. It might indicate that the effort incentive problem has been regulated in practice by many firms by offering at the start of the career wages under the workers' marginal productivity and compensating this difference in the later periods. On the other hand, in services and in trade, we observe the combined relevance of specific human capital and deferred compensation.

Though, the most interesting aspect is the workers' productivity in relation to their cost. It is particularly important as for the employers it may present an incentive to exclude some age groups from the labour market and to give preference to the others. In our study, the relative productivity over cost in manufacturing sector has been found to represent a similar pattern in both skill groups, being the highest for the young, followed by middle-aged and old workers. In both skill groups in services and for low-skilled trade employees the productivity/earnings ratio is the highest for the middle-aged, followed by young and senior workers. This discrepancy between productivity and wage can be a source of employment difficulties particularly for the older low-skilled workers. If prolongation of a working life is one of the political priorities, this fact should be taken into account.

The remainder of the paper is organised as follows. Section 2 discusses the existing theoretical literature as well as empirical evidence on the relation between age, wage and productivity. Section 3 shows the model. In the fourth part an econometric estimation method is presented. The dataset used in this study has been described in part 5 . The estimation results are analysed in section 6 , followed by the conclusions.

\section{Age, wage and productivity: literature review}

\subsection{Theoretical background}

From an employer's perspective, the actual distribution of productivity and earnings across different age groups of the current workforce is very important. While deciding on the production level, a firm has to choose the optimal level of labour input needed to generate the given output. From the economic point of view, "there is an incentive to find the age mix of the workforce that can produce a given output at the least 
cost. This will be the age mix that yields the highest labour productivity and is described as the optimal age mix of the firm's workforce" (Guest and Shacklock, 2005). Although the first aspect, dispersion of earnings, is usually easy to verify, there exists still large uncertainties regarding the productivity distribution across age categories.

Over the $70 \mathrm{~s}$ and $80 \mathrm{~s}$, the relationship between workers' age, wage rates and their productivity has attracted the attention of many researchers. Observations of wage tending to grow with worker's seniority in the firm brought questions on the link between this phenomenon and the evolution of worker's productivity. There exist two important approaches that predict a possible relation between age, wage and productivity: 1) human capital theory suggesting that wage profiles are either equivalent to or flatter than productivity growth over the life cycle and 2) deferred compensation models justifying the need for a wage profile steeper than productivity.

An explanation yielded by human capital theory is based on the idea that wages increase over time due to investments in human capital, particularly investments in the job training (Mincer, 1974; Becker, 1975). Older workers are therefore paid more since they have accumulated more firm-specific human capital and thus they are more productive. The general human capital theory is founded on the assumption that at any point in time workers' wage indicates their productivity. Wages rise over the life cycle at a decreasing rate until depreciation exceeds the level of skill acquisition, yielding a concave earnings profile. According to specific human capital theory, the firm and the worker are assumed to share the investment in worker's training during an initial period. While being trained, workers receive a wage that is lower than wages offered otherwise. Thanks to training, workers become more productive and in later periods gain the returns from the investment through higher marginal products and higher wages. In this case, the resulting wage profiles will be flatter than the productivity path (Hashimoto, 1981).

On the other hand, deferred compensation models underline the possibility of incentive based compensation schemes. A good example of such model is the agency model by Becker and Stigler (1974) and Lazear $(1979,1981)$. In order to discourage workers' shirking, the firm pays young workers below their marginal productivity and later in their career remunerates them over their marginal product. Senior workers receive high salaries, not due to relatively higher productivity but because it creates the appropriate wage incentives for them and for their younger co-workers (Lazear (1981)). Consequently, a steeper wage profile increases workers' effort. In particular, the young workers who hope to stay in the firm are induced to perform at the optimal level. The efficiency wage models (Yellen, 1984; Shapiro and Stiglitz 1984; Bulow and Summers, 1986) point out the importance of the payment above market clearing wages as a mechanism to elicit more effort from the worker when it cannot be fully observable. The fact that wages do not reflect the actual productivity but increase with seniority may result in raised employment difficulties for older workers. Indeed, the deferred compensation contracts may constitute a form of fixed costs for 
the employer. We observe that for certain jobs many firms employ, but tend not to hire older workers (Hutchens, 1986).

According to the arguments mentioned above, it takes time for workers to accumulate education, experience and skill through learning-by-doing. Thus, older workers seem to be more productive than younger ones. However, searching for an optimal age composition of a given workforce, one should not forget that younger cohorts of workers today have much higher education levels than their predecessors. Moreover, within the given enterprise, workers of different age might be less than perfectly substitutable as it is usually assumed. Hence, the optimum age composition of a given workforce might in fact depend on two elements: relative marginal productivity and the degree of substitutability between workers of different age (Lam, 1989).

\subsection{Empirical evidence}

As far as empirical works are concerned, there is relatively little research aiming at productivity and wage data comparison and their correlation with workers' age. Among the recent studies, the contribution of Hellerstein et al. (1999) is worth being mentioned. Using a cross-section plant-level matched employer-employee dataset, the authors analysed the relationship between productivity and wage differentials among manufacturing workers distinguished by different demographic characteristics such as gender, race, marital status, age, education and occupation. In this purpose, a translog production function was jointly estimated with earnings equation. Different categories of workers were assumed to be perfectly substitutable but have potentially different marginal products. The condition of perfectly competitive market was not imposed. The authors allowed possible inequality between relative marginal productivity and relative wage for different workers groups, which could be then interpreted as an indicator of a long-term incentive contracts or discrimination. As a result of their analysis, the authors claimed that in fact wage differentials reflect actual differences in marginal products for most types of workers, particularly for the age category. Consequently, and as underlined by authors, this finding is coherent with the general human capital model by Mincer (1974) mentioned above.

Contrary results have been obtained by Crépon et al. (2002) who expanded the approach by Hellerstein et al. Using the French matched employer-employee panel data set they estimated the Cobb-Douglas production function. The assumption of perfect substitutability between different types of workers was also made. However, instead of parallel estimation of production function and earnings equation as had done Hellerstein et al., only one equation was estimated here. The authors made use of disaggregated data on wages that had been not available to Hellerstein et al. The production function was modified in a way to contain directly a ratio of hourly productivity to wage for different workers categories. Among the findings, the authors stated the existence of a wage productivity gap which tends to expand with age. The wages continue to increase with workers' age whereas the productivity 
stops rising at one point or even declines. It is though unclear whether the old workers are overpaid or the young ones underpaid, or if these both events take place. However, the authors pointed out that increase in wages for workers over 35 cannot be interpreted as reflecting human capital accumulation.

Expanding on the previous methodologies, Aubert and Crépon (2003) made use of the French panel data decomposing the labour force into thinner age groups. Through the estimation of the Cobb-Douglas production function, they found that productivity tends to grow with age up to age of 40 and stabilise afterwards. In all the sectors, workers aged 35-39 appear to be slightly less productive than those over 40 and around 15 to $20 \%$ more productive than young workers under 30 years old. At the same time, the authors found no evidence of a significant difference between wage and productivity that could explain the lower employability of older workers. Although for workers older than 55 a slight decrease in productivity is observed, this result is not statistically significant.

Again, quite different results have been obtained by Hellerstein and Neumark (2006) who refer to their previous article (Hellerstein et al., 1999). They used the same specifications and sample selection criteria but used larger and more representative dataset. The estimated age profiles suggest that the most productive group are prime-age workers (35-54), followed by the younger ones and the seniors (over 55) as the least productive. Furthermore, the wage profile steeper than productivity profile is consistent with the deferred compensation model à la Lazear. Finally, the authors strongly rejected the hypothesis of productivity and wage differentials equality.

Overall, it is evident from this literature review that no clear conclusion can be drawn from earlier research. The current paper continues to investigate the productivity and wage relationship across different age categories of labour trying to overcome one common limitation of previous studies. In our analysis, we introduce the possibility of imperfect substitutability between different categories of workers. In previous empirical works, regardless of the choice of the production function specification in labour and capital (Cobb-Douglas or translog), different workers types were simply summed up according to the assumption of perfect substitutability.

\section{The model: production function with labour as nested CES}

The assumption of perfect substitutability between workers with different characteristics implies that employing one worker while dismissing another one will not lead to any change in the marginal products of either of them as one is perfectly substitutable for another. However, it has been noticed that actually there might arise an interaction of workers within a firm (Lengermann, 2002). The productivity of a certain employee might be affected by co-worker's characteristics. It might 
matter whether the employee works together with a colleague with the same level of skills, similar age, etc. In particular, there exists empirical evidence that the human capitals of young and older workers are imperfect substitutes (Kremer and Thomson, 1998). Hence, labour is not necessarily as easily substitutable as it seems at first glance. This study tries to overcome this problem by choosing such a form of the production function that would take into account the potential imperfect substitutability inside of the workforce - between high-skilled and low-skilled workers and between different age categories within each skill group. In this purpose, we estimate the Cobb-Douglas production function specification in capital $(K)$ and labour $(L)$ whereas the labour input itself takes a form of the nested constant-elasticity-ofsubstitution (CES) function.

Since Arrow et al. (1961) have formulated the function of type CES, numerous studies have been pursued in order to estimate its parameters. However, none of them has been used so far in the context of the labour productivity analysis. As mentioned before, most of research on age-productivity pattern has been based so far on the estimation of the production function. However, by imposing the additive functional form for different categories of labour inputs, they implied a perfect substitution between them.

Figure 1: Scheme of the production structure

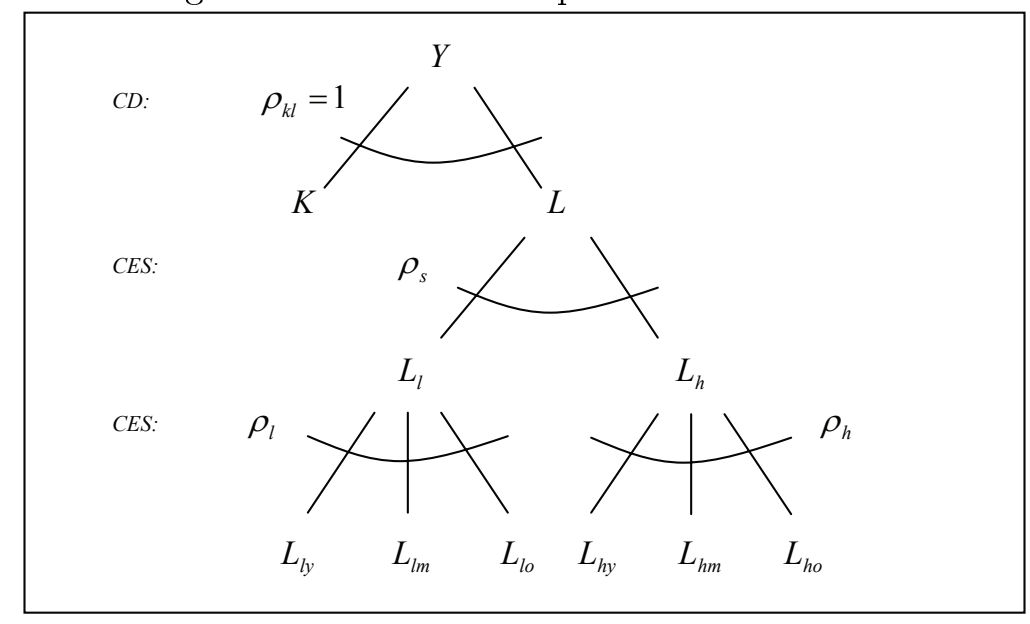

Our benchmark (see Figure 1) takes into account two skill groups (low-skilled $\left(L_{l}\right)$ and high-skilled $\left.\left(L_{h}\right)\right)$ and within each skill category - three age groups of workers (young $\left(L_{y}\right)$, middle-aged $\left(L_{m}\right)$, old $\left(L_{o}\right)$ ). The labour input is allowed to be heterogeneous across but homogeneous within closely defined groups of workers. Thus, it is assumed that the employees belonging to the same skill-age group (e.g. young low-skilled) are perfectly substitutable. 
At the "highest level", our production function takes the Cobb-Douglas form given by:

$$
Y=f(K, L)=A K^{\alpha} L^{\beta}
$$

where $K$ denotes capital, $L$ stands for labour and $A$ is a Hicks neutral technological progress.

At the "second level" the labour aggregate is defined as a CES function of high-skilled and low-skilled workers:

$$
L=\left(\sum_{i} \delta_{i} L_{i}^{\rho_{i}}\right)^{\frac{1}{\rho_{i}}}
$$

where $i$ indicates the skill category. Finally, each skill group of workers is a CES function by itself:

$$
L_{i}=\left[\sum_{j} \delta_{i j} L_{i j}^{\rho_{i j}}\right]^{\frac{1}{\rho_{i j}}}
$$

where the age category is denoted by $j$.

Based on this choice of production function, we aim at estimating the distribution parameters: $\delta_{i}, \delta_{i j}$ as well as the substitution parameters: $\rho_{i}$ and $\rho_{i j}$. The elasticity of substitution is defined as $\sigma=\frac{d \ln \left(x_{1} / x_{2}\right)}{d \ln \left(\frac{\partial Y}{\partial x_{1}} / \frac{\partial Y}{\partial x_{2}}\right)}$ and is a measure of the percentage change in factors demand due to a percentage change in the marginal rate of technical substitution so that the output remains constant. For the case of constant returns to scale it takes the form: $\sigma=\frac{1}{1-\rho}$. The inverse of sigma $\left(\frac{1}{\sigma}\right)$ denotes a change in the marginal rate of technical substitution due to a change in factor proportions so that the output remains constant.

\section{Productivity contribution}

Given the estimates of the production function parameters, we compute the labour marginal product for different categories of labour. In this setting, the constant returns to scale are assumed at the level of labour inputs. According to the Euler's theorem, under homogeneity of degree 1, the labour function might be represented as a sum of its inputs multiplied by their marginal products:

$$
f\left(L_{1}, L_{2}, \ldots, L_{n}\right)=L_{1} \frac{\partial f}{\partial L_{1}}+L_{2} \frac{\partial f}{\partial L_{2}}+\ldots+L_{n} \frac{\partial f}{\partial L_{n}}
$$


Therefore, we can define the marginal product of labour as labour input contribution to the firm-level production.

\section{Skill differentiation}

For the given skill group, it takes the following form:

$$
\begin{gathered}
M P_{i}=\frac{\partial Y}{\partial L} \frac{\partial L}{\partial L_{i}} \\
M P_{i}=A K^{\alpha} \beta\left(\sum_{i} \delta_{i} L_{i}^{\rho_{i}}\right)^{\frac{\beta}{\rho_{i}}-1} \delta_{i} L_{i}^{\rho_{i}-1}
\end{gathered}
$$

The marginal rate of technical substitution depends not only on the factor intensity and the distribution parameter but also on the level of substitution between different labour categories. It shows the rate at which one input may be substituted for another, while maintaining the same level of production. The relative marginal product of labour for workers differentiated by skills is given by:

$$
\frac{M P_{1}}{M P_{2}}=\frac{\partial L / \partial L_{1}}{\partial L / \partial L_{2}}=\lambda=\frac{\delta_{1}}{\delta_{2}}\left(\frac{L_{1}}{L_{2}}\right)^{\rho_{i}-1}
$$

In order to compare productivity contribution over different skill categories, we compute for each enterprise a ratio of marginal product of workers belonging to certain skill group in relation to the average marginal product of labour. For two categories of skills, the ratios take the following form:

$$
\frac{M P_{1}}{M P_{a v}}=\frac{L}{L_{1}+\lambda^{-1} L_{2}} \text { and } \frac{M P_{2}}{M P_{a v}}=\frac{L}{\lambda L_{1}+L_{2}}
$$

where $M P_{a v}$ is the average marginal product of total labour.

Age differentiation

The marginal product of labour for a given age group in a specified skill category is defined as:

$$
\begin{gathered}
M P_{i j}=\frac{\partial Y}{\partial L} \frac{\partial L}{\partial L_{i}} \frac{\partial L_{i}}{\partial L_{i j}} \\
M P_{i}=A K^{\alpha} \beta\left(\sum_{i} \delta_{i} L_{i}^{\rho_{i}}\right)^{\frac{\beta}{\rho_{i}}-1} \delta_{i} L_{i}^{\frac{\rho_{i}}{\rho_{j}}-1} \delta_{i j} L_{i j}^{\rho_{i j}-1}
\end{gathered}
$$

The relative marginal product of any two age groups of workers in a given skill group is:

$$
\frac{M P_{i 1}}{M P_{i 2}}=\frac{\delta_{i 1}}{\delta_{i 2}}\left(\frac{L_{i 1}}{L_{i 2}}\right)^{\rho_{i j}-1}
$$


In our setting, we define relative marginal products as: $\frac{M P_{i Y}}{M P_{i M}}=\varphi, \frac{M P_{i Y}}{M P_{i O}}=\gamma$ and $\frac{M P_{i M}}{M P_{i O}}=\eta$ (where $\mathrm{Y}$ - young, $\mathrm{M}$ - middle-aged, $\mathrm{O}$ - old). The productivity contribution of each age group is given by the ratio of marginal product of respective age group over the average labour marginal productivity of a specific skill group:

$$
\begin{gathered}
\frac{M P_{i Y}}{M P_{a v}}=\frac{L_{i}}{L_{i Y}+\varphi^{-1} L_{i M}+\gamma^{-1} L_{i O}} \\
\frac{M P_{i M}}{M P_{a v}}=\frac{L_{i}}{\varphi L_{i Y}+L_{i M}+\eta^{-1} L_{i O}} \\
\frac{M P_{i O}}{M P_{a v}}=\frac{L_{i}}{\gamma L_{i Y}+\eta L_{i M}+L_{i O}}
\end{gathered}
$$

\section{Wage share}

Our dataset contains rich information on earnings. Hence, according to the procedure above, we compute the share of a distinct age group in the wage bill of the given skill category. Given the productivity contributions and the analogously constructed wage shares, we can compare an earnings-productivity pattern for different categories of workers.

\section{The method}

As far as the econometric estimation of the production function is concerned, one of the major problems to confront is the possible endogeneity of inputs resulting in inconsistency of direct estimators. In fact, the input demand might be correlated with the productivity shocks unobservable by the econometrician but observed or predicted by the firm (Marschak and Andrews, 1944). A profit maximizing (or costminimizing) firm facing positive productivity shocks will expand its production and thus increase the inputs level. On the other hand, a consequence of the negative shocks will be a production decrease and lower input usage. A particular concern about the endogeneity bias concerns the analysis of labour disaggregated by age. Aubert and Crépon (2003) draw attention to the fact that enterprise could respond to negative productivity shocks by postponing its hiring decisions. Then, one might observe production decline accompanied by ageing workforce. On the other hand, positive shocks could encourage the firm to hire some young workers. As a result, the rise in output would be generated by relatively younger workforce. The causality problem that appears in such case is whether firms employing relatively older workforce are less productive or if firms employ relatively older workforce because they are less productive. 
In order to obtain consistent estimates of the production function parameters, we use the method developed by Levinsohn and Petrin (2003). The procedure consists in including in the estimation equation a proxy for the productivity shocks potentially observed by firms while making input decisions ${ }^{1}$. Hence, the parameters identification is based on the variation in output and inputs unrelated to these productivity shocks.

We consider the following value added production function:

$$
y_{i t}=\beta_{0}+\alpha k_{i t}+\beta \ln \left(\left(\sum_{i} \delta_{i}\left(\sum_{j} \delta_{i j} L_{i j i t}^{\rho_{i j}}\right)^{\frac{\rho_{i}}{\rho_{i j}}}\right)^{\frac{1}{\rho_{i}}}\right)+\omega_{i t}+\eta_{i t}
$$

The error term is composed of 2 elements: $\omega_{i t}$ denoting productivity shocks likely observed by the firm and $\eta_{i t}$ having no impact on the firm's inputs decisions. $y_{i t}$ is a natural logarithm of value added and $k_{i t}$ denotes a natural logarithm of capital.

Following LP, we assume that firms decide on the level of capital at $t-1$, thus capital is a dynamic input. The labour and the intermediate input (materials) $m_{i t}$ are chosen at time $t$. The productivity shock $\omega_{i t}$ is assumed to follow a first order Markov process:

$$
p\left(\omega_{i t} \mid I_{i t-1}\right)=p\left(\omega_{i t} \mid \omega_{i t-1}\right)
$$

where $I$ is firm's $i$ 's information set at $t$.

The approach adopted in the current work consists in using intermediate input as a proxy for the unobservable productivity shocks. Hence, materials control for the part of the error term correlated with inputs. Given the above timing assumptions, the firm's demand for the intermediate input $m_{i t}$ is assumed to depend on the state variables $k_{i t}$ and $\omega_{i t}$.

$$
m_{i t}=f_{t}\left(k_{i t}, \omega_{i t}\right)
$$

The assumption that intermediate input is strictly monotonic in the productivity shock allows inversion of materials demand function for $\omega_{i t}$

$$
\omega_{i t}=f_{t}^{-1}\left(k_{i t}, m_{i t}\right)
$$

and substituting it into the production function so that the following first stage equation is obtained:

\footnotetext{
${ }^{1}$ An alternative approach toward endogeneity bias has been developed by Arellano and Bond (1991) and consisted in estimating an equation in first-differences with appropriately lagged levels as instruments. However, since lagged variables in levels are often weak instruments for contemporaneous differences, in case of highly persistent data, the method appeared to suffer from finite sample bias and poor precision of the estimates. This problem has been further addressed by Blundell and Bond (1998), Blundell and Bond (2000), Blundell, Bond and Windmeijer (2000) and Windmeijer (2000). Within this framework lagged levels are used as instruments for contemporaneous differences and lagged differences as instruments for contemporaneous levels.
} 


$$
y_{i t}=\beta \ln \left(\left(\sum_{i} \delta_{i}\left(\sum_{j} \delta_{i j} L_{i j i t}^{\rho_{i j}}\right)^{\frac{\rho_{i}}{\rho_{i j}}}\right)^{\frac{1}{\rho_{i}}}\right)+\phi_{i t}\left(k_{i t}, m_{i t}\right)+\eta_{i t}
$$

where $\phi_{i t}\left(k_{i t}, m_{i t}\right)=\beta_{0}+\alpha k_{i t}+\omega_{i t}\left(k_{i t}, m_{i t}\right)$.

By substituting the third-order polynomial in $k_{i t}$ and $m_{i t}$, in place of $\phi_{i t}\left(k_{i t}, m_{i t}\right)$ :

$$
y_{i t}=\delta_{0}+\beta \ln \left(\left(\sum_{i} \delta_{i}\left(\sum_{j} \delta_{i j} L_{i j i t}^{\rho_{i j}}\right)^{\frac{\rho_{i}}{\rho_{i j}}}\right)^{\frac{1}{\rho_{i}}}\right)+\sum_{j=0}^{3} \sum_{n=0}^{3-j} \delta_{j n} k_{i t}^{j} m_{i t}^{n}+\eta_{i t}
$$

we can consistently estimate parameters for labour using the non-linear least squares method. In this setting, $\beta_{0}$ is not separately identified from the intercept of the polynomial $\delta_{0}$.

The second stage of the procedure helps us to identify the coefficient for capital. It starts with computing the estimated value of $\hat{\phi}_{i t}$ :

$$
\hat{\phi_{i t}}=\hat{y_{i t}}-\hat{\beta} \ln \left(\left(\sum_{i} \hat{\delta}_{i}\left(\sum_{j} \hat{\delta}_{i j} L_{i j i t}^{\hat{\rho}_{i j}}\right)^{\frac{\hat{\rho}_{i}}{\hat{\rho}_{i j}}}\right)^{\frac{1}{\hat{\rho}_{i}}}\right)=\hat{\delta}_{0}+\sum_{j=0}^{3} \sum_{n=0}^{3-j} \hat{\delta}_{j n} k_{i t}^{j} m_{i t}^{n}
$$

For any candidate value $\alpha^{*}$, we can compute the prediction for $\omega_{i t}$ for all periods $t$ :

$$
\hat{\omega}_{i t}=\hat{\phi}_{i t}-\alpha^{*} k_{i t}
$$

Given these values, we regress non-parametrically $\omega_{i t}$ on its lagged term $\omega_{i t-1}$ :

$$
\hat{\omega}_{i t}=\gamma_{0}+\gamma_{1} \omega_{i t-1}+\gamma_{2} \omega_{i t-1}^{2}+\gamma_{3} \omega_{i t-1}^{3}+\epsilon_{i t}
$$

in order to get the residual $\xi_{i t}$ and the conditional expectation $E\left[\omega_{i t} \mid \omega_{i t-1}\right]=$ $\omega_{i t}-\xi_{i t}$. 
Given labour coefficients, a guess value $\alpha^{*}$ and $E\left[\omega_{i t} \mid \omega_{i t-1}\right]$, we can find a consistent estimate of a parameter for capital which is a solution to minimizing a squared sum of a sample residual of our production function:

$$
\min _{\alpha^{*}} \sum_{t}\left(\eta_{i t}+\xi_{i t}\right)^{2}=\min _{\alpha^{*}} \sum_{t}\left(y_{i t}-\hat{\beta} l n\left(\left(\sum_{i} \hat{\delta}_{i}\left(\sum_{j} \hat{\delta}_{i j} L_{i j i t}^{\hat{\rho}_{i j}}\right)^{\frac{\hat{\rho}_{i}}{\hat{\rho}_{i j}}}\right)^{\frac{1}{\hat{\rho}_{i}}}\right)-\alpha^{*} k_{i t}-E\left[\omega_{i t} \mid \omega_{i t-1}\right]\right)^{2}
$$

The asymptotic standard errors for estimated parameters might be constructed using a bootstrap approach.

\section{$5 \quad$ Data and summary statistics}

The dataset used in this study covers a short panel of data for years 2003 and 2004 for manufacturing, services and trade sectors in France. It comes from merging two different data sources: Bénéfices Réels Normaux (BRN) and Déclarations Administratives de Données Sociales (DADS). They both constitute mandatory employers' reports to the Fiscal Office. The BRN consists of firms' balance sheets and provides important information on the employers' output, capital stock and economic sector. The DADS contains rich data on the characteristics of the workforce. The number of hours worked is decomposed by workers' age and occupation. The valuable information on earnings allows to measure the share of a distinct labour category in total wage bill. However, the dataset is not without imperfection. Unfortunately, the DADS does not contain any information on workers' education level and tenure.

In order to distinguish among workers according to the level of skills, we make use of the available decomposition by occupation. The DADS employment data are arranged by occupation according to the French socio-professional classification. This classification is used in collective agreements for wage determination. A higher level of education places a worker directly on the "higher starting point" and experience then allows further wage increases. However, as emphasised by Thesmar and Thoenig (2000), this classification, based on the mix of education and experience, contains no information about the task-assignment. Therefore, the senior personnel ("Cadres") may include high-ranked directors as well as e.g. consultants without any supervision duty. Using this occupation classification, we distinguish two skills categories of workers: high-skilled and low-skilled. The high-skilled correspond to employers, the senior and intermediate personnel. The office and sales employees as well as blue collar workers are included in a low-skilled category. For details, see Table 1. 
Table 1: Skill classification

\begin{tabular}{ll}
\hline \multicolumn{1}{c}{ High-skilled labour } & \multicolumn{1}{c}{ Low-skilled labour } \\
\hline Employers & Non-manual workers \\
Craftsmen & Office employees \\
Traders & Sales workers \\
Employers (of 50 or more employees) & Manual workers \\
Liberal professions and senior personnel & Skilled industrial manual workers \\
Liberal professions & Skilled craftsman \\
Professors and scientific professions & Drivers \\
Artistic professions & Skilled handling, storage and \\
Senior administrative personnel & transport workers \\
Engineers and senior technicians & Unskilled industrial workers \\
Intermediate personnel & Unskilled artisans \\
Medical and social services & \\
Intermediate administrative personnel & \\
Technicians & \\
Foreman, supervisors & \\
\hline
\end{tabular}

As far as the labour force composition is concerned, three age classes are considered within each skill group. We define young workers as those who are under 30 years old, the middle-aged workers between 30 and 50, and the senior employees as those over 50. The reason why we choose these age classes is twofold. Firstly, since we keep only firms where all age categories are present, the condition of sufficient number of observations within each age group must have been met. Secondly, the data analysis revealed that the employment level is much more heterogenous among the young (up to 30) and among seniors (over 50) compared to the middle-aged (30-50) group. In particular, the lowest employment characterise the young under 25 and older persons over 55. Nowadays, many young people decide to prolong their education and, thus, enter relatively late into labour market. On the other hand, an earlier exit from the labour market is still quite common among the seniors.

For the purpose of our analysis, the volume of production is represented by value added and the employment level is measured by number of hours worked. It permits to distinguish between part-time and full-time employees. The aberrant values have been eliminated. Value added, capital, labour cost and employment are required to take positive values. Only firms employing at least fifty workers have been considered. As a result of these operations, the final dataset contains 15'992 observations.

As far as a sector division is concerned, manufacturing, trade and services are distinguished according to NES16 (Nomenclature économique de synthèse en 16 postes). The agriculture, forestry and fishing as well as construction sector (due to high ratio 
of seasonal workers) have been excluded from manufacturing. Administration and financial services have not been takes into account in services sector.

The summary statistics of the main variables as well as the labour force composition by age and skills are represented in Table 2 . We can observe substantial differences with respect to age-employment and age-earnings patterns of workers belonging to different skill groups.

\section{Employment pattern}

First of all, we can see that in all three sectors, i.e. manufacturing, trade and services, the workers between 30 and 50 years old account for around 0.6 of the total hours worked. The employment of the young and the seniors is considerably lower. If we look separately at each skill group, we can notice that among the highskilled, the number of hours worked by older workers exceeds those of the young. In particular, the discrepancies are the biggest in manufacturing. The opposite pattern characterises the low-skilled employees (with exception of manufacturing sector), where the young are more numerous than the seniors.

Earnings pattern

As far as the age-earnings pattern is concerned, we observe an increasing profile of hourly earnings for both skill groups in all the sectors. The remuneration of the young workers is the lowest and the oldest employees are paid the most. According to economic intuition, high-skilled workers are better paid than the low-skilled. Taking into account the desaggregation by skills, the profile of hourly earnings of the lowskilled is considerably flatter - the differences between consecutive age groups are at average of $15 \%$ and $4 \%$. Interestingly, the respective mean differentials in salaries between the high-skilled age groups are of $40 \%$ and $30 \%$. Consequently, the range of salaries in this skill category is wider. 
Table 2: Sample statistics, DADS-BRN, 2004

\begin{tabular}{|c|c|c|c|c|c|c|c|c|c|}
\hline \multirow[t]{2}{*}{ Variables* } & \multicolumn{3}{|c|}{ Manufacturing } & \multicolumn{3}{|c|}{ Services } & \multicolumn{3}{|c|}{ Trade } \\
\hline & share & mean & sdv & share & mean & $\operatorname{sdv}$ & share & mean & $\operatorname{sdv}$ \\
\hline In value added & & -2.67 & 1.15 & & -3.01 & 1.26 & & -3.04 & 1.04 \\
\hline ln capital & & -2.57 & 1.54 & & -3.32 & 1.85 & & -3.28 & 1.38 \\
\hline ln capital (t-1) & & -2.61 & 1.57 & & -3.38 & 1.88 & & -3.34 & 1.39 \\
\hline In materials & & -2.81 & 1.63 & & -5.54 & 2.06 & & -6.81 & 2.15 \\
\hline In materials (t-1) & & -2.86 & 1.63 & & -5.59 & 2.03 & & -6.82 & 2.17 \\
\hline \multicolumn{10}{|l|}{ Hours worked by age: } \\
\hline total & 1.00 & 4.85 & 22.47 & 1.00 & 5.28 & 44.68 & 1.00 & 3.83 & 22.14 \\
\hline$(L y)$ young $(<30)$ & 0.18 & 0.79 & 4.04 & 0.21 & 1.09 & 4.99 & 0.28 & 1.08 & 6.74 \\
\hline$(\mathrm{Lm})$ middle-aged $(30-50)$ & 0.60 & 2.85 & 11.68 & 0.58 & 3.07 & 24.65 & 0.57 & 2.19 & 12.90 \\
\hline$(L o)$ old $(>50)$ & 0.22 & 1.21 & 7.09 & 0.21 & 1.11 & 15.93 & 0.15 & 0.56 & 2.76 \\
\hline \multicolumn{10}{|c|}{ Hours worked by skills and age: } \\
\hline$(L l)$ low-skilled & 0.59 & 2.85 & 13.07 & 0.58 & 3.05 & 18.63 & 0.65 & 2.50 & 17.41 \\
\hline (Lly) young & 0.18 & 0.52 & 2.61 & 0.25 & 0.74 & 3.57 & 0.34 & 0.86 & 5.88 \\
\hline$(L l m)$ middle-aged & 0.58 & 1.65 & 6.65 & 0.56 & 1.72 & 9.64 & 0.53 & 1.32 & 9.70 \\
\hline (Llo) old & 0.24 & 0.68 & 4.05 & 0.19 & 0.59 & 6.24 & 0.13 & 0.32 & 1.99 \\
\hline (Lh) high-skilled & 0.41 & 2.00 & 10.24 & 0.42 & 2.23 & 26.92 & 0.35 & 1.33 & 5.40 \\
\hline (Lhy) young & 0.14 & 0.27 & 1.52 & 0.16 & 0.35 & 1.71 & 0.17 & 0.22 & 1.04 \\
\hline$(\mathrm{Lhm})$ middle-aged & 0.59 & 1.19 & 5.65 & 0.61 & 1.36 & 15.59 & 0.65 & 0.87 & 3.65 \\
\hline (Lho) old & 0.27 & 0.53 & 3.27 & 0.23 & 0.51 & 9.94 & 0.18 & 0.24 & 0.86 \\
\hline \multicolumn{10}{|c|}{ * All variables have been standardised (divided by 100000 before taking logarithms) } \\
\hline \multirow[t]{2}{*}{ Variables } & \multicolumn{3}{|c|}{ Manufacturing } & \multicolumn{3}{|c|}{ Services } & \multicolumn{3}{|c|}{ Trade } \\
\hline & share & mean & $\operatorname{sdv}$ & share & mean & $\operatorname{sdv}$ & share & mean & $\operatorname{sdv}$ \\
\hline \multicolumn{10}{|l|}{ Hourly earnings by age: } \\
\hline total & 1.00 & 15.66 & 3.93 & 1.00 & 14.65 & 5.84 & 1.00 & 14.36 & 4.42 \\
\hline$(L y)$ young $(<30)$ & 0.14 & 12.00 & 2.46 & 0.20 & 11.74 & 5.51 & 0.22 & 10.70 & 2.42 \\
\hline$(\mathrm{Lm})$ middle-aged $(30-50)$ & 0.60 & 15.70 & 3.98 & 0.58 & 14.90 & 8.04 & 0.58 & 14.87 & 4.52 \\
\hline$(L o)$ old $(>50)$ & 0.26 & 18.99 & 6.75 & 0.22 & 17.90 & 7.70 & 0.20 & 18.58 & 7.57 \\
\hline \multicolumn{10}{|c|}{ Hourly earnings by skills and age: } \\
\hline$(L l)$ low-skilled & 0.52 & 12.13 & 2.44 & 0.51 & 11.20 & 2.12 & 0.50 & 10.63 & 1.92 \\
\hline (Lly) young & 0.17 & 10.54 & 1.97 & 0.25 & 10.15 & 1.72 & 0.30 & 9.49 & 1.72 \\
\hline$(L l m)$ middle-aged & 0.60 & 12.35 & 2.53 & 0.56 & 11.46 & 2.39 & 0.55 & 11.03 & 7.49 \\
\hline$(L l o)$ old & 0.23 & 12.92 & 3.08 & 0.20 & 11.95 & 2.88 & 0.15 & 11.54 & 5.76 \\
\hline & 0.48 & 22.13 & 4.84 & 0.49 & 19.94 & 6.96 & 0.50 & 20.62 & 5.32 \\
\hline (Lhy) young & 0.11 & 15.05 & 4.52 & 0.16 & 14.58 & 6.44 & 0.11 & 14.28 & 0.36 \\
\hline (Lhm) middle-aged & 0.59 & 21.73 & 4.86 & 0.58 & 19.88 & 7.14 & 0.62 & 20.36 & 8.54 \\
\hline (Lho) old & 0.30 & 28.00 & 10.83 & 0.26 & 25.96 & 18.89 & 0.27 & 26.66 & 7.75 \\
\hline Number of observations & & 8185 & & & 4498 & & & 3309 & \\
\hline
\end{tabular}




\section{Results}

We start our analysis with estimation of the production function whose structure has been detailed in Part 3. Based on the estimated parameters, we will generate and compare the age-productivity and age-earnings pattern for the low-skilled and for the high-skilled workers belonging to different sectors. First, on the basis of median values, we will present the general pattern. Afterwards, we will analyse the density estimations of inter-firm distributions of productivity and earnings. The detailed analysis will be carried out consecutively by skills and then by age within each skill group.

\subsection{Econometric results}

Our estimation procedure consists in estimating three following models:

model (1) with labour differentiated by skills:

$$
Y=A K^{\alpha}\left(\delta_{s} L l^{\rho_{s}}+\left(1-\delta_{s}\right) L h^{\rho_{s}}\right)^{\frac{\beta}{\rho_{s}}}
$$

model (2) with labour differentiated by age:

$$
Y=A K^{\alpha}\left(\delta_{y} L y^{\rho_{a}}+\delta_{m} L m^{\rho_{a}}+\left(1-\delta_{y}-\delta_{m}\right) L o^{\rho_{a}}\right)^{\frac{\beta}{\rho_{a}}}
$$

model (3) with labour differentiated simultaneously by age and skills:

$$
\begin{aligned}
Y=A K^{\alpha} & \left(\gamma\left(\delta_{l y} L l y^{\rho_{l}}+\delta_{l m} L l m^{\rho_{l}}+\left(1-\delta_{l y}-\delta_{l m}\right) L l o^{\rho_{l}}\right)^{\frac{\rho_{s}}{\rho_{l}}}+\right. \\
& \left.+(1-\gamma)\left(\delta_{h y} L h y^{\rho_{h}}+\delta_{h m} L_{h m}^{\rho_{h}}+\left(1-\delta_{h y}-\delta_{h m}\right) L_{h o}^{\rho_{h}}\right)^{\frac{\rho_{s}}{\rho_{h}}}\right)^{\frac{\beta}{\rho_{s}}}
\end{aligned}
$$

The estimation results for each sector of the production function are presented respectively in Tables 3 to $6^{2}$. The first column refers to the results obtained according to the nonlinear least squares method. The second column reports the production function estimates based on the two-stages procedure by Levinsohn and Petrin (2003) controlling for the potential endogeneity. Since parameters enter in the function in a nonlinear way, estimators only have asymptotic validity. The standard errors have been constructed according to a bootstrap approach with 200 replications.

Elasticity of substitution

\footnotetext{
${ }^{2}$ In order to check the validity and robustness of our results, in the appendix we present the results of the estimation of different models with sub-sector dummy variables in manufacturing and services sectors (Tables 17 and 18). The results confirm the robustness of the estimates after introducing the sub-sector controls.
} 
In models with labour differentiated by skills, a inter-skill substitution parameter $\rho_{s}$ surprisingly has been found to converge to 1 in all the sectors (see Table 3) which implies perfect substitutability between workers belonging to different skill groups. We suppose that this result might come from the classification on low-skilled and high-skill workers. It is possible that, in fact, there are not much differences in skill levels for certain socio-professional categories. To circumvent this drawback, we have run the estimation with 3 skill groups, taking apart the intermediate personnel but it did not have much impact on the results. In the sequel, estimations are thus made directly under the constraint $\rho_{s}=1$.

Table 3: Production function estimates for each sector, labour differentiated by skills, model (1)

\begin{tabular}{|c|c|c|c|c|c|c|}
\hline \multirow[t]{2}{*}{ Parameters } & \multicolumn{2}{|c|}{ Manufacturing } & \multicolumn{2}{|c|}{ Services } & \multicolumn{2}{|c|}{ Trade } \\
\hline & NLLS & LP & NLLS & LP & NLLS & LP \\
\hline$c$ & $\begin{array}{l}-2.197 * * * \\
(0.015)\end{array}$ & & $\begin{array}{l}-2.243 * * * \\
(0.022)\end{array}$ & & $\begin{array}{l}-2.421 * * * \\
(0.027)\end{array}$ & \\
\hline$\alpha$ & $\begin{array}{l}0.187 * * * \\
(0.005)\end{array}$ & $\begin{array}{l}0.301 * * * \\
(0.047)\end{array}$ & $\begin{array}{l}0.234 * * * \\
(0.006)\end{array}$ & $\begin{array}{l}0.173^{* * *} \\
(0.038)\end{array}$ & $\begin{array}{l}0.118 * * * \\
(0.008)\end{array}$ & $\begin{array}{l}0.164 * * * \\
(0.038)\end{array}$ \\
\hline$\beta$ & $\begin{array}{l}0.829 * * * \\
(0.008)\end{array}$ & $\begin{array}{l}0.729 * * * \\
(0.009)\end{array}$ & $\begin{array}{l}0.743 * * * \\
(0.011)\end{array}$ & $\begin{array}{l}0.699 * * * \\
(0.023)\end{array}$ & $\begin{array}{l}0.903 * * * \\
(0.012)\end{array}$ & $\begin{array}{l}0.875 * * * \\
(0.015)\end{array}$ \\
\hline$\delta_{s}$ & $\begin{array}{l}0.231 \text { *** } \\
(0.011)\end{array}$ & $\begin{array}{l}0.207 * * * \\
(0.015)\end{array}$ & $\begin{array}{l}0.190 * * * \\
(0.033)\end{array}$ & $\begin{array}{l}0.163 * * * \\
(0.043)\end{array}$ & $\begin{array}{l}0.216 \text { *** } \\
(0.016)\end{array}$ & $\begin{array}{l}0.216 * * * \\
(0.019)\end{array}$ \\
\hline$\rho_{s}$ & $\begin{array}{l}1.257 * * * \\
(0.078)\end{array}$ & $\begin{array}{l}1.327 * * * \\
(0.093)\end{array}$ & $\begin{array}{l}2.408 * * * \\
(0.322)\end{array}$ & $\begin{array}{l}2.649 * * * \\
(0.512)\end{array}$ & $\begin{array}{l}1.336^{* * * *} \\
(0.111)\end{array}$ & $\begin{array}{l}1.328 * * * \\
(0.118)\end{array}$ \\
\hline No of obs. & 8185 & 8185 & 4498 & 4498 & 3309 & 3309 \\
\hline
\end{tabular}

The elasticity of substitution between workers differentiated only by age appears quite different by sector (see Table 4). The substitution parameter $\rho_{a}$ is not significantly different from zero in services, between zero and one in manufacturing and higher than unity in the trade sector. These results imply different work organization in each sector. They hold in the model with labour differentiated simultaneously by age and skills (see Table 5). There we observe that the substitution parameter $\rho_{h}$ in the services sector is not significantly different from 0 . In trade, the respective parameter for both skill groups tends to converge to 1 . 
Table 4: Production function estimates for each sector, labour differentiated by age, model (2)

\begin{tabular}{|c|c|c|c|c|c|c|}
\hline \multirow[t]{2}{*}{ Parameters } & \multicolumn{2}{|c|}{ Manufacturing } & \multicolumn{2}{|c|}{ Services } & \multicolumn{2}{|c|}{ Trade } \\
\hline & NLLS & LP & NLLS & LP & NLLS & LP \\
\hline$c$ & $\begin{array}{l}-1.947 * * * \\
(0.022)\end{array}$ & & $\begin{array}{l}-2.067 * * * \\
(0.036)\end{array}$ & & $\begin{array}{l}-2.287 * * * \\
(0.039)\end{array}$ & \\
\hline$\alpha$ & $\begin{array}{l}0.200 * * * \\
(0.005)\end{array}$ & $\begin{array}{l}0.278 * * * \\
(0.038)\end{array}$ & $\begin{array}{l}0.240 * * * \\
(0.006)\end{array}$ & $\begin{array}{l}0.186^{* * *} \\
(0.037)\end{array}$ & $\begin{array}{l}0.104 * * * \\
(0.008)\end{array}$ & $\begin{array}{l}0.159 * * * \\
(0.038)\end{array}$ \\
\hline$\beta$ & $\begin{array}{l}0.835 \text { *** } \\
(0.008)\end{array}$ & $\begin{array}{l}0.726 * * * \\
(0.010)\end{array}$ & $\begin{array}{l}0.735^{* * *} \\
(0.011)\end{array}$ & $\begin{array}{l}0.691 \text { *** } \\
(0.021)\end{array}$ & $\begin{array}{l}0.921 \text { *** } \\
(0.013)\end{array}$ & $\begin{array}{l}0.879 * * * \\
(0.016)\end{array}$ \\
\hline$\delta_{y}$ & $\begin{array}{l}0.314^{* * * *} \\
(0.018)\end{array}$ & $\begin{array}{l}0.281 * * * \\
(0.020)\end{array}$ & $\begin{array}{l}0.221 * * * \\
(0.027)\end{array}$ & $\begin{array}{l}0.238^{* * *} \\
(0.036)\end{array}$ & $\begin{array}{l}0.070^{* * *} \\
(0.019)\end{array}$ & $\begin{array}{l}0.074 * * * \\
(0.017)\end{array}$ \\
\hline$\delta_{m}$ & $\begin{array}{l}0.443^{* * *} \\
(0.026)\end{array}$ & $\begin{array}{l}0.491 * * * \\
(0.032)\end{array}$ & $\begin{array}{l}0.479 * * * \\
(0.057)\end{array}$ & $\begin{array}{l}0.540 * * * \\
(0.084)\end{array}$ & $\begin{array}{l}0.326 * * * \\
(0.064)\end{array}$ & $\begin{array}{l}0.357 * * * \\
(0.072)\end{array}$ \\
\hline$\delta_{o}$ & 0.243 & $\begin{array}{l}0.228^{* * *} \\
(0.017)\end{array}$ & 0.300 & $\begin{array}{l}0.222 * * \\
(0.094)\end{array}$ & 0.604 & $\begin{array}{l}0.569^{* * *} \\
(0.074)\end{array}$ \\
\hline$\rho_{a}$ & $\begin{array}{l}0.367 * * * \\
(0.074)\end{array}$ & $\begin{array}{l}0.246 * * * \\
(0.094)\end{array}$ & $\begin{array}{l}1.321 * * * \\
(0.314)\end{array}$ & $\begin{array}{l}0.955 \\
(1.482)\end{array}$ & $\begin{array}{l}1.912 * * * \\
(0.340)\end{array}$ & $\begin{array}{l}1.848^{* * * *} \\
(0.366)\end{array}$ \\
\hline No of obs. & 8185 & 8185 & 4498 & 4498 & 3309 & 3309 \\
\hline
\end{tabular}


Table 5: Production function estimates for each sector, labour differentiated by age and skills, model (3)

\begin{tabular}{|c|c|c|c|c|c|c|}
\hline \multirow[t]{2}{*}{ Parameters } & \multicolumn{2}{|c|}{ Manufacturing } & \multicolumn{2}{|c|}{ Services } & \multicolumn{2}{|c|}{ Trade } \\
\hline & NLLS & LP & NLLS & LP & NLLS & LP \\
\hline$c$ & $\begin{array}{l}-1.294 * * * \\
(0.021)\end{array}$ & & $\begin{array}{l}-1.538 * * * \\
(0.037)\end{array}$ & & $\begin{array}{l}-1.538^{* * * *} \\
(0.036)\end{array}$ & \\
\hline$\alpha$ & $\begin{array}{l}0.186 * * * \\
(0.004)\end{array}$ & $\begin{array}{l}0.291 * * * \\
(0.045)\end{array}$ & $\begin{array}{l}0.222 * * * \\
(0.006)\end{array}$ & $\begin{array}{l}0.166^{* * *} \\
(0.040)\end{array}$ & $\begin{array}{l}0.112 * * * \\
(0.008)\end{array}$ & $\begin{array}{l}0.159^{* * *} \\
(0.036)\end{array}$ \\
\hline$\beta$ & $\begin{array}{l}0.833^{* * *} \\
(0.007)\end{array}$ & $\begin{array}{l}0.736 * * * \\
(0.009)\end{array}$ & $\begin{array}{l}0.759 * * * \\
(0.011)\end{array}$ & $\begin{array}{l}0.717 \text { *** } \\
(0.022)\end{array}$ & $\begin{array}{l}0.911 \text { *** } \\
(0.012)\end{array}$ & $\begin{array}{l}0.879 * * * \\
(0.015)\end{array}$ \\
\hline$\gamma$ & $\begin{array}{l}0.274 * * * \\
(0.013)\end{array}$ & $\begin{array}{l}0.254 * * * \\
(0.015)\end{array}$ & $\begin{array}{l}0.367 * * * \\
(0.027)\end{array}$ & $\begin{array}{l}0.357 \text { *** } \\
(0.023)\end{array}$ & $\begin{array}{l}0.226^{* * * *} \\
(0.021)\end{array}$ & $\begin{array}{l}0.215^{* * * *} \\
(0.026)\end{array}$ \\
\hline $1-\gamma$ & 0.725 & $\begin{array}{l}0.746^{* * *} \\
(0.015)\end{array}$ & 0.633 & $\begin{array}{l}0.643^{* * *} \\
(0.023)\end{array}$ & 0.774 & $\begin{array}{l}0.785^{* * *} \\
(0.026)\end{array}$ \\
\hline$\delta_{l y}$ & $\begin{array}{l}0.437 \text { *** } \\
(0.034)\end{array}$ & $\begin{array}{l}0.395 * * * \\
(0.032)\end{array}$ & $\begin{array}{l}0.275^{* * *} \\
(0.036)\end{array}$ & $\begin{array}{l}0.282 * * * \\
(0.030)\end{array}$ & $\begin{array}{l}0.236^{\text {**** }} \\
(0.042)\end{array}$ & $\begin{array}{l}0.263 * * * \\
(0.046)\end{array}$ \\
\hline$\delta_{l m}$ & $\begin{array}{l}0.417 \text { *** } \\
(0.046)\end{array}$ & $\begin{array}{l}0.458 * * * \\
(0.052)\end{array}$ & $\begin{array}{l}0.497 * * * \\
(0.075)\end{array}$ & $\begin{array}{l}0.558 * * * \\
(0.068)\end{array}$ & $\begin{array}{l}0.608 \text { *** } \\
(0.099)\end{array}$ & $\begin{array}{l}0.673 \text { *** } \\
(0.124)\end{array}$ \\
\hline$\delta_{l o}$ & 0.145 & $\begin{array}{l}0.147 * * * \\
(0.030)\end{array}$ & 0.227 & $\begin{array}{l}0.159 * * \\
(0.065)\end{array}$ & 0.155 & $\begin{array}{l}0.063 \\
(0.121)\end{array}$ \\
\hline$\rho_{l}$ & $\begin{array}{l}0.463 * * * \\
(0.119)\end{array}$ & $\begin{array}{l}0.372 * * * \\
(0.120)\end{array}$ & $\begin{array}{l}0.810 * * * \\
(0.286)\end{array}$ & $\begin{array}{l}0.574 * * * \\
(0.186)\end{array}$ & $\begin{array}{l}1.341 * * * \\
(0.427)\end{array}$ & $\begin{array}{l}1.039 * * \\
(0.518)\end{array}$ \\
\hline$\delta_{h y}$ & $\begin{array}{l}0.247 * * * \\
(0.029)\end{array}$ & $\begin{array}{l}0.242 * * * \\
(0.031)\end{array}$ & $\begin{array}{l}0.117 * * \\
(0.061)\end{array}$ & $\begin{array}{l}0.134 \\
(0.099)\end{array}$ & $\begin{array}{l}0.209^{* * *} \\
(0.032)\end{array}$ & $\begin{array}{l}0.192 * * * \\
(0.058)\end{array}$ \\
\hline$\delta_{h m}$ & $\begin{array}{l}0.405^{* * * *} \\
(0.036)\end{array}$ & $\begin{array}{l}0.432 * * * \\
(0.042)\end{array}$ & $\begin{array}{l}0.372 * * * \\
(0.103)\end{array}$ & $\begin{array}{l}0.388^{* *} \\
(0.181)\end{array}$ & $\begin{array}{l}0.421 \text { *** } \\
(0.049)\end{array}$ & $\begin{array}{l}0.427 * * * \\
(0.091)\end{array}$ \\
\hline$\delta_{h o}$ & 0.347 & $\begin{array}{l}0.326 * * * \\
(0.026)\end{array}$ & 0.511 & $\begin{array}{l}0.477 * \\
(0.268)\end{array}$ & 0.370 & $\begin{array}{l}0.380 * * * \\
(0.054)\end{array}$ \\
\hline$\rho_{h}$ & $\begin{array}{l}0.725^{* * * *} \\
(0.122)\end{array}$ & $\begin{array}{l}0.594 * * * \\
(0.132)\end{array}$ & $\begin{array}{l}2.302 * * * \\
(0.820)\end{array}$ & $\begin{array}{l}2.065 \\
(10.898)\end{array}$ & $\begin{array}{l}0.789 * * * \\
(0.169)\end{array}$ & $\begin{array}{l}0.792 * * \\
(0.324)\end{array}$ \\
\hline No of obs. & 8185 & 8185 & 4498 & 4498 & 3309 & 3309 \\
\hline
\end{tabular}

The results shown in Table 6 include already all these constraints on parameters $\rho_{l}$ and $\rho_{h}$. We observe that low-skilled services workers of different age are closer substitutes than the high-skilled ones. Interestingly, in manufacturing, the highskilled workers have been found more easily substitutable between each other than the low-skilled. 
Table 6: Production function estimates for each sector, labour differentiated by age and skills, constrained model (3)

\begin{tabular}{|c|c|c|c|c|c|c|}
\hline \multirow[t]{2}{*}{ Parameters } & \multicolumn{2}{|c|}{ Manufacturing } & \multicolumn{2}{|c|}{ Services } & \multicolumn{2}{|c|}{ Trade } \\
\hline & NLLS & LP & NLLS & LP & NLLS & LP \\
\hline$c$ & $\begin{array}{l}-1.294 * * * \\
(0.021)\end{array}$ & & $\begin{array}{l}-1.587 * * * \\
(0.035)\end{array}$ & & $\begin{array}{l}-1.534 * * * \\
(0.035)\end{array}$ & \\
\hline$\alpha$ & $\begin{array}{l}0.186 * * * \\
(0.004)\end{array}$ & $\begin{array}{l}0.291^{* * *} \\
(0.045)\end{array}$ & $\begin{array}{l}0.222 * * * \\
(0.006)\end{array}$ & $\begin{array}{l}0.165^{* * *} \\
(0.040)\end{array}$ & $\begin{array}{l}0.113 * * * \\
(0.008)\end{array}$ & $\begin{array}{l}0.159 * * * \\
(0.036)\end{array}$ \\
\hline$\beta$ & $\begin{array}{l}0.833^{* * *} \\
(0.007)\end{array}$ & $\begin{array}{l}0.736 \text { *** } \\
(0.009)\end{array}$ & $\begin{array}{l}0.751 * * * \\
(0.011)\end{array}$ & $\begin{array}{l}0.709 * * * \\
(0.022)\end{array}$ & $\begin{array}{l}0.910 * * * \\
(0.012)\end{array}$ & $\begin{array}{l}0.878^{* * *} \\
(0.015)\end{array}$ \\
\hline$\gamma$ & $\begin{array}{l}0.274 * * * \\
(0.013)\end{array}$ & $\begin{array}{l}0.254 * * * \\
(0.015)\end{array}$ & $\begin{array}{l}0.405 * * * \\
(0.027)\end{array}$ & $\begin{array}{l}0.387 * * * \\
(0.024)\end{array}$ & $\begin{array}{l}0.218 * * * \\
(0.019)\end{array}$ & $\begin{array}{l}0.213 \text { *** } \\
(0.022)\end{array}$ \\
\hline $1-\gamma$ & 0.725 & $\begin{array}{l}0.746^{* * * *} \\
(0.015)\end{array}$ & 0.595 & $\begin{array}{l}0.612 * * * \\
(0.024)\end{array}$ & 0.782 & $\begin{array}{l}0.786^{* * *} \\
(0.022)\end{array}$ \\
\hline$\delta_{l y}$ & $\begin{array}{l}0.437 * * * \\
(0.034)\end{array}$ & $\begin{array}{l}0.395^{* * *} \\
(0.032)\end{array}$ & $\begin{array}{l}0.252 * * * \\
(0.038)\end{array}$ & $\begin{array}{l}0.263 * * \\
(0.030)\end{array}$ & $\begin{array}{l}0.240 * * * \\
(0.037)\end{array}$ & $\begin{array}{l}0.262 * * * \\
(0.037)\end{array}$ \\
\hline$\delta_{l m}$ & $\begin{array}{l}0.417 * * * \\
(0.046)\end{array}$ & $\begin{array}{l}0.458^{* * * *} \\
(0.052)\end{array}$ & $\begin{array}{l}0.430 * * * \\
(0.071)\end{array}$ & $\begin{array}{l}0.505 \\
(0.074)\end{array}$ & $\begin{array}{l}0.668^{* * * *} \\
(0.085)\end{array}$ & $\begin{array}{l}0.680 * * * \\
(0.085)\end{array}$ \\
\hline$\delta_{l o}$ & 0.145 & $\begin{array}{l}0.147 * * * \\
(0.030)\end{array}$ & 0.318 & $\begin{array}{l}0.231 \text { ** } \\
(0.079)\end{array}$ & 0.092 & $\begin{array}{l}0.058 \\
(0.091)\end{array}$ \\
\hline$\rho_{l}$ & $\begin{array}{l}0.463 * * * \\
(0.119)\end{array}$ & $\begin{array}{l}0.372 * * * \\
(0.120)\end{array}$ & $\begin{array}{l}1.062 * * * \\
(0.324)\end{array}$ & $\begin{array}{l}0.778^{* * * *} \\
(0.230)\end{array}$ & 1 & 1 \\
\hline$\delta_{h y}$ & $\begin{array}{l}0.247 * * * \\
(0.029)\end{array}$ & $\begin{array}{l}0.242 * * * \\
(0.031)\end{array}$ & $\begin{array}{l}0.081 * * \\
(0.028)\end{array}$ & $\begin{array}{l}0.110 \\
(0.034)\end{array}$ & $\begin{array}{l}0.222 * * * \\
(0.032)\end{array}$ & $\begin{array}{l}0.201^{* * *} \\
(0.056)\end{array}$ \\
\hline$\delta_{h m}$ & $\begin{array}{l}0.405^{* * * *} \\
(0.036)\end{array}$ & $\begin{array}{l}0.432 * * * \\
(0.042)\end{array}$ & $\begin{array}{l}0.832 * * * \\
(0.045)\end{array}$ & $\begin{array}{l}0.802 * * \\
(0.052)\end{array}$ & $\begin{array}{l}0.373 \text { *** } \\
(0.029)\end{array}$ & $\begin{array}{l}0.385^{* * *} \\
(0.038)\end{array}$ \\
\hline$\delta_{h o}$ & 0.347 & $\begin{array}{l}0.326 * * * \\
(0.026)\end{array}$ & 0.085 & $\begin{array}{l}0.087 * \\
(0.034)\end{array}$ & 0.404 & $\begin{array}{l}0.414 * * * \\
(0.039)\end{array}$ \\
\hline$\rho_{h}$ & $\begin{array}{l}0.725^{* * * *} \\
(0.122)\end{array}$ & $\begin{array}{l}0.594 * * * \\
(0.132)\end{array}$ & 0 & 0 & 1 & 1 \\
\hline \multicolumn{7}{|c|}{ elasticity of substitution : $\sigma=1 /(1-\rho)$} \\
\hline Lly-Llm-Llo & & 1.59 & & 4.5 & & $\rightarrow \infty$ \\
\hline Lhy-Lhm-Lho & & 3.64 & & 1 & & $\rightarrow \infty$ \\
\hline No of obs. & 8185 & 8185 & 4498 & 4498 & 3309 & 3309 \\
\hline
\end{tabular}

\section{Control for endogenity bias}

The nonlinear least squares estimates appear to suffer from the endogeneity bias implying existing correlation between productivity and input choices. Interestingly, the existing bias has different character in distinct sectors. In manufacturing and in trade, the NLLS method tends to underestimate the capital coefficient $(\alpha)$ and overestimate the labour coefficients $(\beta)$. Such situation takes place if capital and labour are positively correlated and labour's correlation with the productivity shock is higher than capital's correlation. On the other hand, in services, both NLLS coeffi- 
cients $\alpha$ and $\beta$ tend to be biased up. It might be the case when only labour responds to the shock and at the same time capital and labour are positively correlated ${ }^{3}$.

We can also observe interesting results regarding the potential endogeneity bias within the labour input. In the model with labour differentiated by skills (model (1) and (3)), we see the coefficients of low-skilled workers to be slightly biased up in all the sectors. Among different age categories, the coefficients of old workers (as well as young workers in manufacturing) are overestimated. Although these biases are not statistically significant, they might however indicate that the correlation of these categories of labour with the productivity shock is higher. It could imply that more of this labour type is hired/made redundant in response to the positive/negative productivity shock.

Within the labour differentiated simultaneously by age and skills, in all the sectors, the NLLS estimates tend to underestimate the middle-aged workers coefficient. For other skill-age categories, the results are more sector-specific. Among the underestimated coefficients suggesting lower correlation with the productivity shock, we find: young low-skilled workers in services and trade, old low-skilled workers in manufacturing, young high-skilled workers in services and senior high-skilled workers in trade. Nevertheless, these biases stay not very significant.

\subsection{Age-productivity and age-earnings profile: general pattern}

According to the methodology presented in part 3, we construct the productivity contributions and wage shares for different categories of workers. Thanks to the information on earnings in the dataset, the share of a distinct age group in the wage bill of a given skill category may be easily computed. Based on the estimated parameters values corrected for the endogeneity bias (right columns of Table 6), we address the question of the marginal product of labour. Consequently, we can compare an earnings-productivity pattern for different skill and age categories of workers in three different sectors.

A general tendency regarding productivity contributions and wage shares is presented in Table 7 and is given by the median. In our case, where the data are not necessarily symmetrically distributed, the median is a form of "average" that gives a better idea of a general pattern than given by the mean. In fact, if data are symmetrically distributed, using either the mean or the median gives almost identical results. In case of skewed distributions, using the mean could be misleading as means are very sensitive to outliers.

\footnotetext{
${ }^{3}$ According to Levinsohn and Petrin (2003), these two cases might be the most relevant for short panels because between-firm variation often plays a dominant role in identification and, in this dimension, capital and labour tend to be highly correlated.
} 
Table 7: Age-productivity and age-earnings pattern Manufacturing

low-skilled

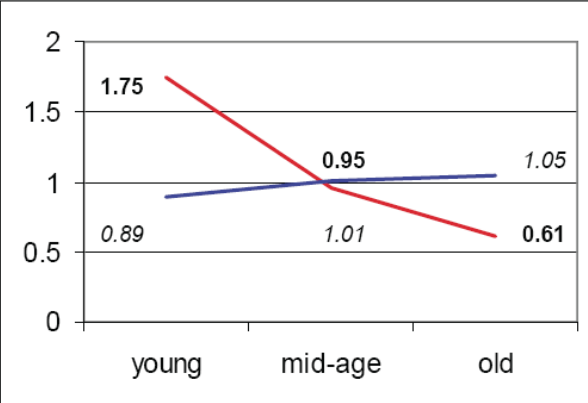

high-skilled

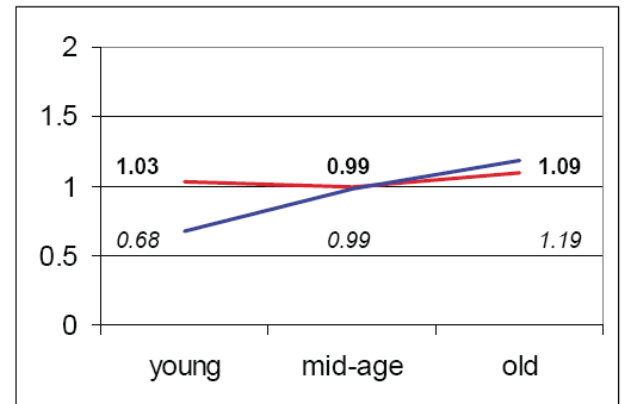

Services

low-skilled

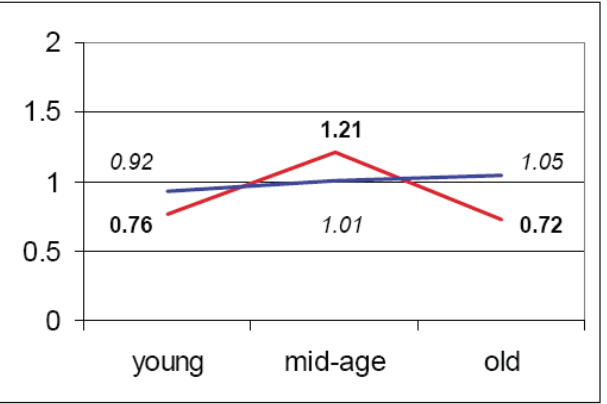

high-skilled

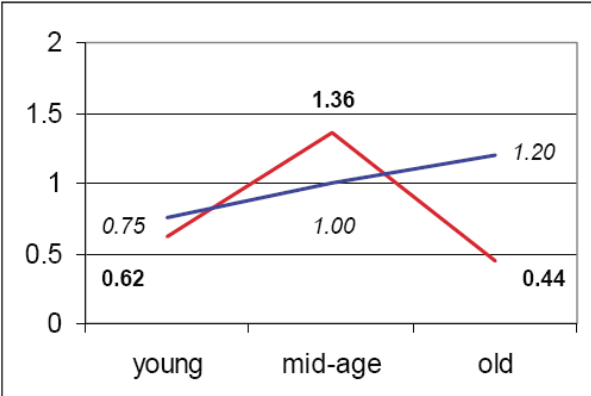

Trade

low-skilled

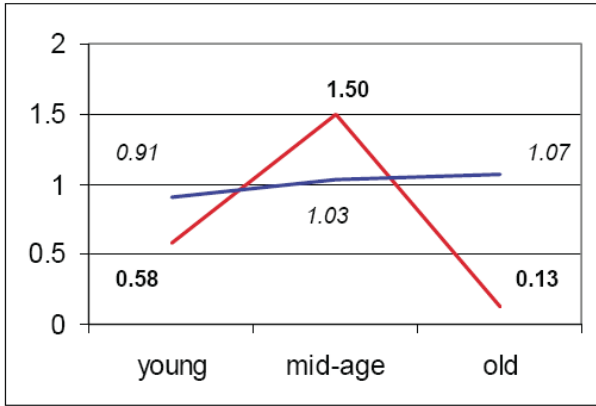

high-skilled

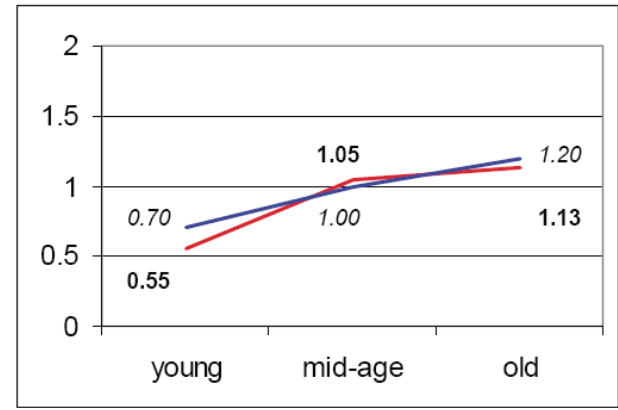

— productivity contribution (median)

— wage share (median) 
Assuming that there exists an "average enterprise", we observe throughout the sectors and for both skill categories of workers that wage shares vary substantially less than workers' productivity. In manufacturing, the age-productivity and age-earnings profiles are compatible with a deferred compensation system. It might indicate that, in this sector, the effort incentive problem has been regulated in practice by many firms by offering at the start of the career wages under the workers' marginal productivity and compensating this difference in the later periods. On the other hand, in services and in trade, we observe the combined relevance of specific human capital and deferred compensation. For young employees, the productivity profile is steeper than the wage profile suggesting that investments in specific human capital are important at the beginning of employees' careers. For older workers, the wage share is higher than productivity contribution implying rather an incentive based compensation scheme.

Interestingly, for the high-skilled workers in manufacturing, there is not much difference in productivity across the age groups. Though, it is the highest for the oldest employees. In trade, the productivity has a clearly increasing slope. Importantly, in both of these sectors, the profile of wage share of middle-aged and senior workers does not diverge much from the profile of productivity contribution.

At the same time, in the low-skilled category, the estimated workers' productivity is clearly the lowest for the oldest workers. It is possible that certain low-skilled employees, as time is passing, either quit the labour market (e.g. due to early retirement) or upgrade their qualifications and move to the high-skilled occupations. Thus, the senior workers who stay in the low-skilled jobs are those who are not very productive. The similar phenomenon could be also observed among the people in high-skilled occupations. Seniors working as highly-skilled experts are not an exception in certain jobs. Hence, the seniors who are still working tend to be those relatively more productive. In order to control for this selection phenomenon, time series on labour turnover would be needed.

\subsection{Density estimations}

The results for the "average enterprise" are interesting but do not reflect all the complexity of variation in wage shares and productivity contributions across the enterprises. Therefore, we also analyse the shape of the density functions of wage and productivity distributions. In this purpose, we make use of kernel density estimation which is a non-parametric way of estimating the probability density function. It is clearly smoother than some other density estimators such as histogram. The univariate kernel density estimator is computed using:

$$
\hat{f}(x)=\frac{1}{n h} \sum_{i=1}^{n} K\left[\frac{x-X_{i}}{h}\right]
$$


where $K$ is the Epanechnikov Kernel function and $h$ is a smoothing parameter called the bandwith (Parzen, 1962).

\subsubsection{Productivity}

The productivity contribution $\left(M P_{i j} / M P_{i} a v\right)$ is defined as a ratio of marginal product of a specific age group $(j)$ over the average labour marginal product of a given skill group $(i)$. If the productivity of a certain age group equals to the sector average, this ratio equals to 1 . In Tables 8 - 10, this case is expressed as a black vertical line. Since the distribution of productivity across the age groups is highly sector-specific, we analyse each sector separately as follows.

\section{Manufacturing}

In manufacturing, as shown in Table 8, the productivity of low-skilled workers across the enterprises is characterised by higher variability than the one of high-skilled workers. In general, the median absolute deviations are higher and there are more positive outliers. If we look closer at different age groups, we can notice that in both skills groups a greater variability in productivity is observed among young and older workers. At the same time, the productivity contribution of the middle-aged group does not vary that much between the firms. Its values are well concentrated around the sector average.

Certain particularities can be observed within each skills category. Among the lowskilled, the young workers appear the most productive. Most of them have productivity contribution exceeding the sector average $(>1)$ and we observe many positive outliers. On the other hand, the great majority of older workers have productivity below the average $(<1)$. Though a few positive outliers occur.

The density estimations concerning the high-skilled workers are quite different. The

productivity distributions of different age groups have much more symmetric shape and the median value is quite close to the sector average. In this skill category, the older workers appear the most productive group. More than half of them are more productive than an average high-skilled person.

\section{Services}

Table 9 reveals a pattern of productivity distribution in the sector of services. This time, a higher inter-firm variability can be observed for the high-skilled employees. Both, the median absolute deviations as well as positive outliers take much higher values for this type of workers.

Nevertheless, this time the productivity profile across the age groups is similar in both skill groups. The middle-aged workers are found clearly the most productive. 
Table 8: Share in average marginal productivity (manufacturing)

\begin{tabular}{|l|c|c|c|c|}
\hline & median & $\begin{array}{c}\text { median absolute } \\
\text { deviation }\end{array}$ & $\min$ & $\max$ \\
\hline low-skilled & & & & \\
$\quad$ young & 1.75 & 0.48 & 0.73 & 44.44 \\
middle-aged & 0.95 & 0.07 & 0.77 & 3.88 \\
old & 0.61 & 0.13 & 0.33 & 16.18 \\
high-skilled & & & & \\
$\quad$ young & 1.03 & 0.17 & 0.63 & 7.55 \\
middle-aged & 0.99 & 0.05 & 0.89 & 2.77 \\
old & 1.09 & 0.16 & 0.76 & 8.96 \\
\hline
\end{tabular}

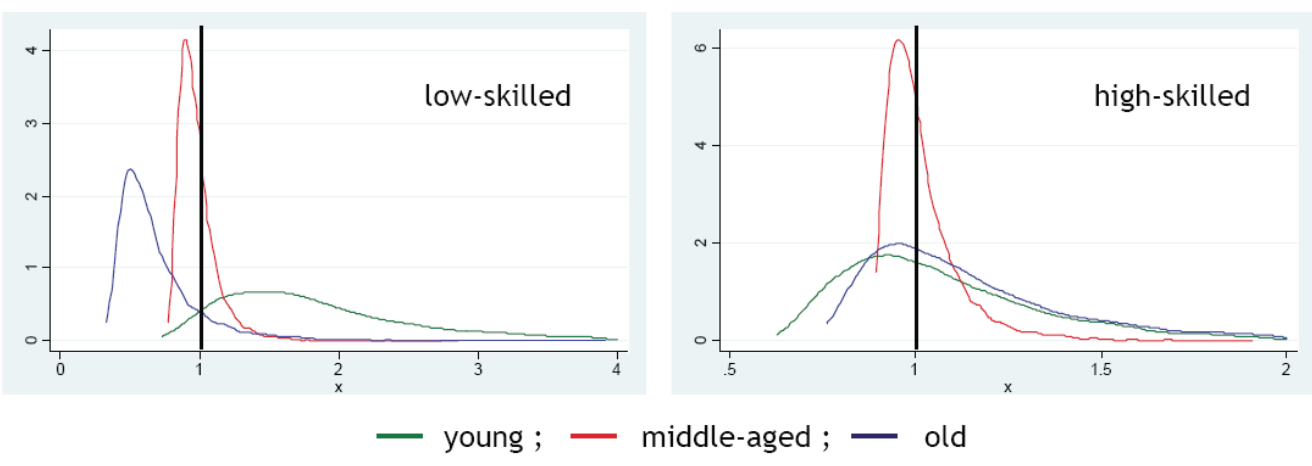

Almost all of them reach productivity higher than sector average $(>1)$. In contrast, most of juniors and seniors are characterised by the productivity below the mean. However, there are some positive outliers, especially among the high-skilled workers. 
Table 9: Share in average marginal productivity (services)

\begin{tabular}{|l|c|c|c|c|}
\hline & median & $\begin{array}{c}\text { median absolute } \\
\text { deviation }\end{array}$ & $\min$ & $\max$ \\
\hline low-skilled & & 0.05 & 0.68 & 1.96 \\
$\quad$ young & 0.76 & 0.07 & 0.99 & 3.74 \\
middle-aged & 1.21 & 0.06 & 0.62 & 2.53 \\
old & 0.72 & & & \\
high-skilled & & 0.27 & 0.13 & 47.11 \\
young & 0.62 & 0.19 & 0.83 & 27.85 \\
middle-aged & 1.36 & 0.18 & 0.09 & 119.00 \\
old & 0.44 & &
\end{tabular}

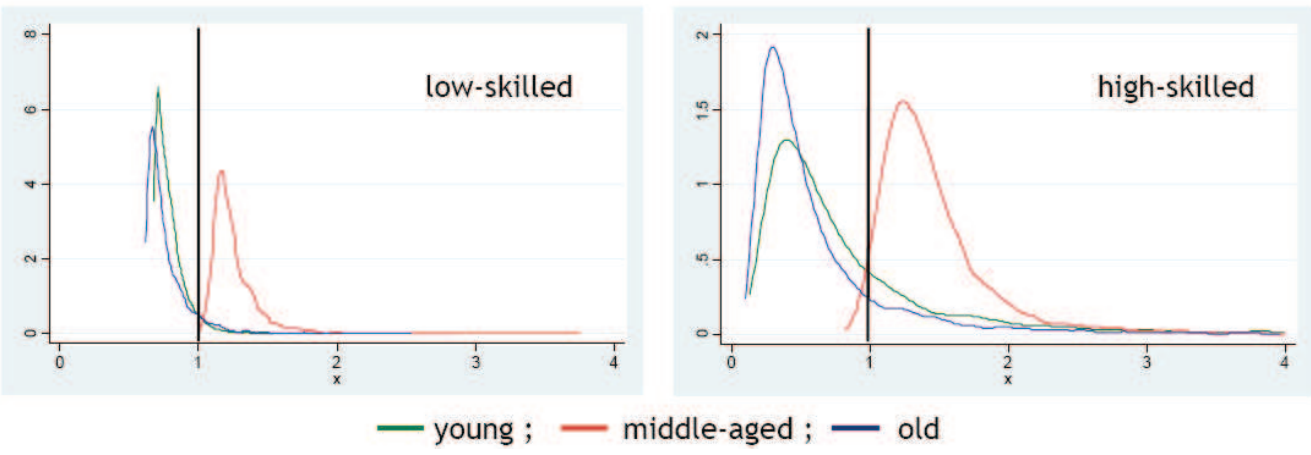

Trade

As can be seen in Table 10, in trade the productivity pattern is very different from those observed in other sectors. First of all, the productivity variability within narrowly defined age groups is much lower. Furthermore, there are large differences between skill groups. Among the low-skilled workers, the productivity distributions almost do not cross each other. The middle-aged workers are the most productive with the productivity contribution over the sector average in all the enterprises. The productivity of young and seniors is considerably lower, well below the sector mean.

A very different situation takes place within the high-skilled category of workers. Here, the senior are the most productive group followed closely by middle-aged workers with very similar productivity distribution. The young high-skilled employees are significantly less productive. 
Table 10: Share in average marginal productivity (trade)

\begin{tabular}{|l|c|c|c|c|}
\hline & median & $\begin{array}{c}\text { median absolute } \\
\text { deviation }\end{array}$ & $\min$ & $\max$ \\
\hline low-skilled & & 0.04 & 0.42 & 1.17 \\
$\quad$ young & 0.58 & 0.11 & 1.10 & 3.03 \\
$\quad$ middle-aged & 1.50 & 0.01 & 0.09 & 0.26 \\
$\quad$ old & 0.13 & & & \\
high-skilled & & 0.02 & 0.49 & 0.82 \\
$\quad$ young & 0.55 & 0.03 & 0.95 & 1.57 \\
middle-aged & 1.05 & 0.04 & 1.03 & 1.69 \\
$\quad$ old & 1.13 & & \\
\hline
\end{tabular}

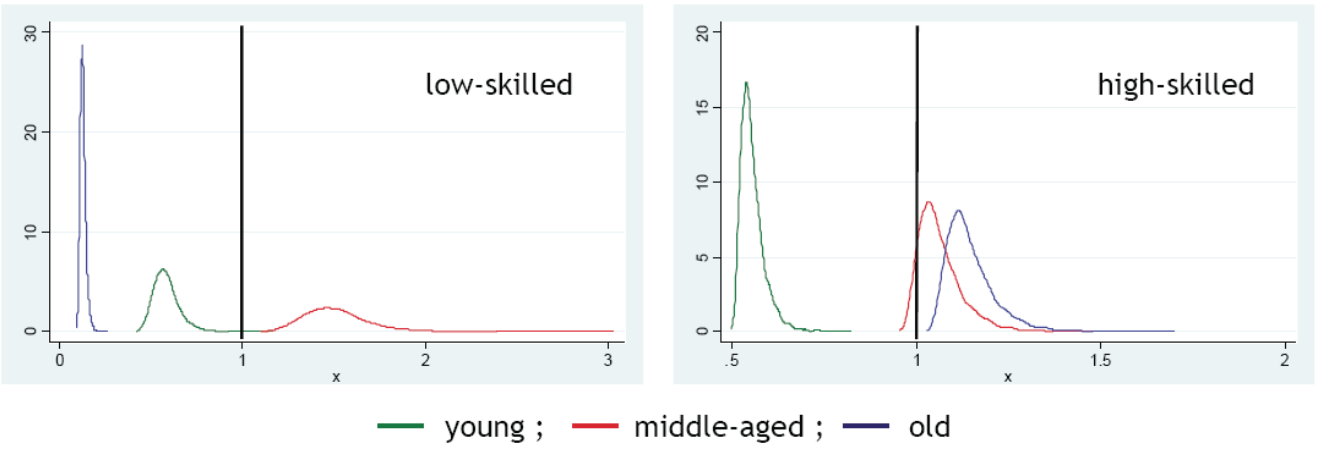

\subsubsection{Earnings}

The distributions of wages over age and skill categories are presented in Tables 11, 12 and 13. The wage share $\left(W_{i j} / W_{i} a v\right)$ is defined as a ratio of earnings of a specific age group $(j)$ over the average earnings of a given skill group $(i)$. The ratio equals to 1 (expressed in the tables by a black vertical line) if earnings correspond to the sector average.

In all the sectors we observe a very similar pattern. In general, wage rates vary substantially less than workers' productivity. It is in line with empirical evidence against the paradigm of wage and marginal productivity equality (Frank (1984), Campbell and Kamlani (1997)). As far as differentiation by skills is concerned, wages of low-skilled workers are less variable than those of the high-skilled.

In the low-skilled category, the middle-aged group of workers is characterised by the earnings distribution with the lowest variability, well concentrated around the mean. The earnings variability of young and older workers is very comparable.

Within the high-skilled group we observe more positive outliers, in particular for senior workers, possibly due to better remuneration offered to high-skilled employees with a long tenure. The distribution of earnings for the middle-aged workers is the least variable, followed by young and senior employees. 
Table 11: Share in average wage (manufacturing)

\begin{tabular}{|l|c|c|c|c|}
\hline & median & $\begin{array}{c}\text { median absolute } \\
\text { deviation }\end{array}$ & $\min$ & $\max$ \\
\hline low-skilled & & & & \\
$\quad$ young & 0.89 & 0.05 & 0.05 & 2.74 \\
middle-aged & 1.01 & 0.02 & 0.54 & 1.49 \\
old & 1.05 & 0.04 & 0.44 & 4.79 \\
high-skilled & & & & \\
$\quad$ young & 0.68 & 0.08 & 0.01 & 2.94 \\
middle-aged & 0.99 & 0.05 & 0.40 & 2.23 \\
old & 1.19 & 0.13 & 0.35 & 8.34 \\
\hline
\end{tabular}

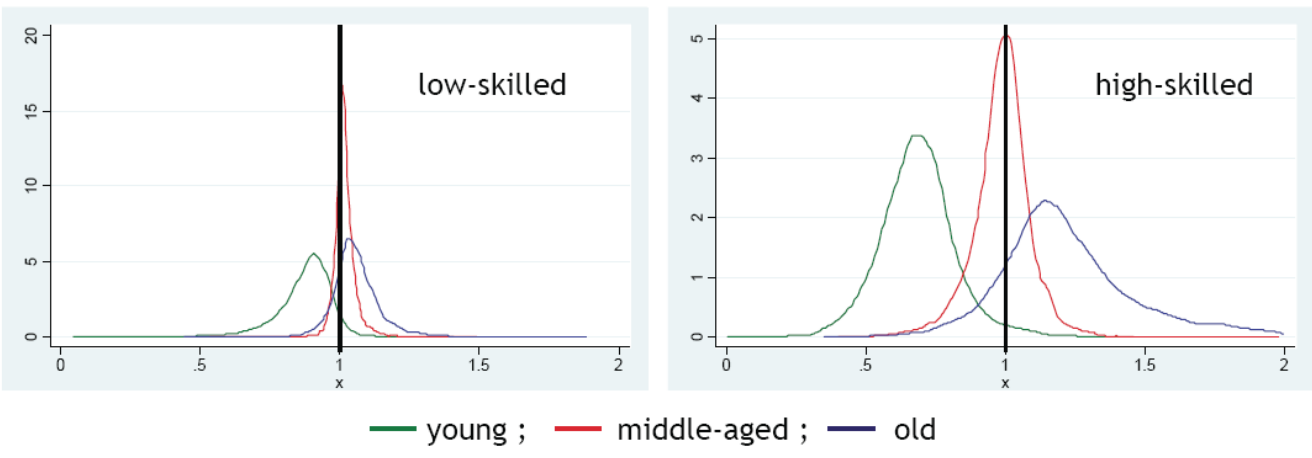

Table 12: Share in average wage (services)

\begin{tabular}{|l|c|c|c|c|}
\hline & median & $\begin{array}{c}\text { median absolute } \\
\text { deviation }\end{array}$ & $\min$ & $\max$ \\
\hline low-skilled & & 0.04 & 0.24 & 1.43 \\
$\quad$ young & 0.92 & 0.02 & 0.78 & 1.80 \\
$\quad$ middle-aged & 1.01 & 0.05 & 0.34 & 3.52 \\
$\quad$ old & 1.05 & 0.08 & 0.02 & \\
high-skilled & & 0.05 & 0.31 & 5.02 \\
$\quad$ young & 0.75 & 0.15 & 0.28 & 37.84 \\
$\quad$ middle-aged & 1.00 & & & \\
$\quad$ old & 1.20 & & & \\
\hline
\end{tabular}
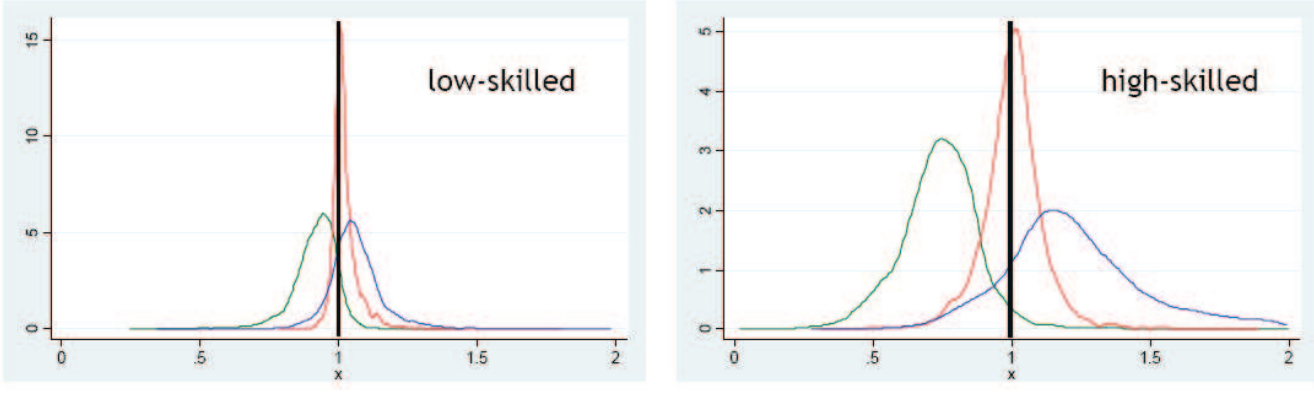

— young ; — middle-aged ; — old 
Table 13: Share in average wage (trade)

\begin{tabular}{|l|c|c|c|c|}
\hline & median & $\begin{array}{c}\text { median absolute } \\
\text { deviation }\end{array}$ & $\min$ & $\max$ \\
\hline low-skilled & & 0.05 & 0.13 & 1.33 \\
$\quad$ young & 0.91 & 0.02 & 0.82 & 1.51 \\
middle-aged & 1.03 & 0.05 & 0.59 & 2.32 \\
old & 1.07 & & & \\
high-skilled & & 0.09 & 0.02 & 3.75 \\
young & 0.70 & 0.06 & 0.42 & 1.83 \\
middle-aged & 1.00 & 0.17 & 0.38 & 5.49 \\
old & 1.20 & & & \\
\hline
\end{tabular}

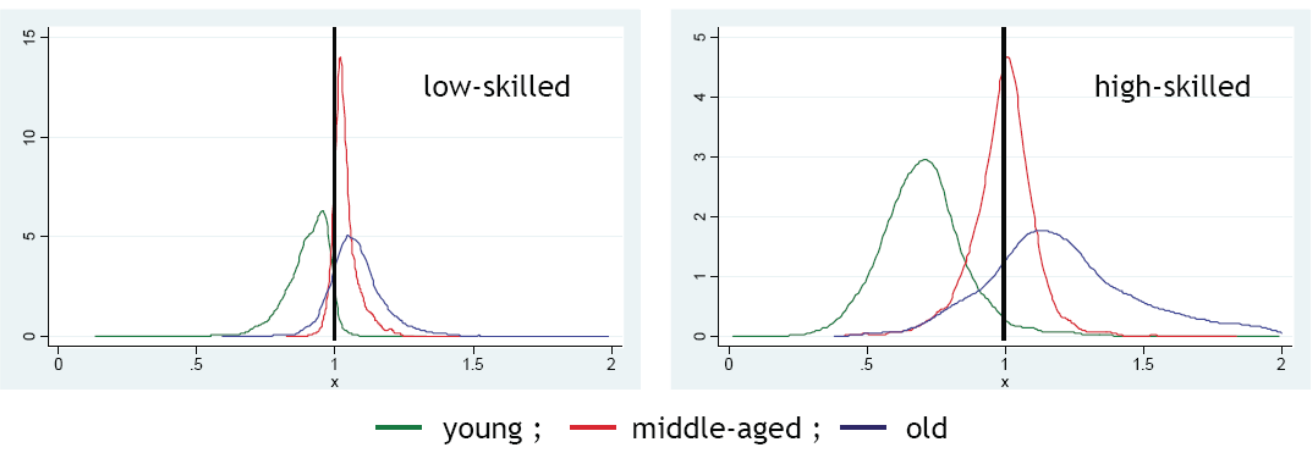

\subsubsection{Productivity/earnings ratio}

The most interesting aspect from the perspective of the employer is the workers' productivity in relation to their cost. It is particularly important as for the employers it may present an incentive to exclude some age groups from the labour market and to give preference to the others.

It is possible that some workers having the same productivity are paid differently or that some other are paid equally but have different productivities. Therefore, apart of analysing the productivity distribution separately from wages, we consider also the inter-firm distribution of the productivity/earnings ratio with respect to all age and skill groups (see Tables 14, 15 and 16). We define it as $\frac{M P_{i j}}{M P_{i} a v} / \frac{W_{i j}}{W_{i} a v}$.

It appears that in manufacturing the relative productivity over the wage ratio is the highest for the young, followed by the middle-aged and the old. The possible explanation could be that the young are paid the least and at the same time they are highly motivated to work hard. If there exists incomplete information about the workers' ability at the beginning of their career, the young workers might exert much 
more effort in order to suggest high ability level and keep their current job (Grund and Westergård-Nielsen, 2005). The high variability in distribution for the young comes from the positive outliers.

This productivity/earnings ratio decreases with age for both skill groups. It means that the attractiveness of an employee for the employer decreases with age. Though, it is not so strong for the high-skilled workers. The distribution of the ratio shows higher variability for the older compared to the middle-aged workers. It has a lower median and a significant majority of observations are below the sector average.

Table 14: Ratio of relative productivity over relative wage (manufacturing)

\begin{tabular}{|l|c|c|c|c|}
\hline & median & $\begin{array}{c}\text { median absolute } \\
\text { deviation }\end{array}$ & $\min$ & $\max$ \\
\hline low-skilled & & 0.59 & 0.56 & 106 \\
$\quad$ young & 2.02 & 0.07 & 0.70 & 4.03 \\
$\quad$ middle-aged & 0.93 & 0.13 & 0.24 & 17.77 \\
$\quad$ old & 0.58 & & & \\
high-skilled & & 0.33 & 0.60 & 291 \\
$\quad$ young & 1.53 & 0.07 & 0.73 & 3.82 \\
middle-aged & 1.00 & 0.13 & 0.32 & 10.17 \\
$\quad$ old & 0.88 & & & \\
\hline
\end{tabular}

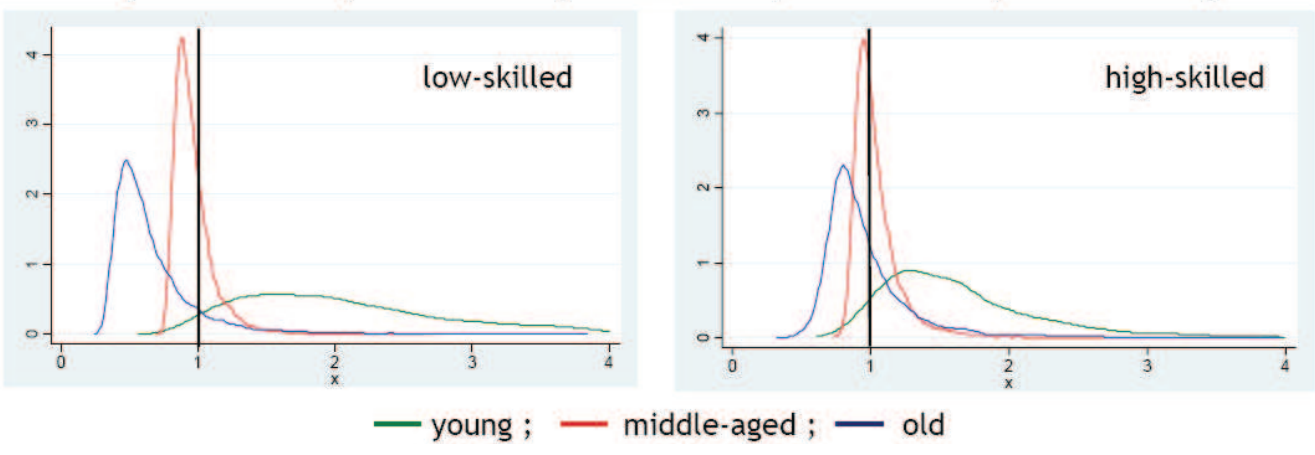

In services sector, we observe lower variability of the ratio among the low-skilled workers. The high variability for the high-skilled comes, among others, from the positive outliers in this group. In both skill categories, the productivity/earnings ratio is the highest for the middle-aged, followed by young and senior workers. Thus, similarly to the pure productivity profile, the middle-aged workers are the most attractive employees. However, the biggest positive outliers are found among the junior workers. 
Table 15: Ratio of relative productivity over relative wage (services)

\begin{tabular}{|l|c|c|c|c|}
\hline & median & $\begin{array}{c}\text { median absolute } \\
\text { deviation }\end{array}$ & $\min$ & $\max$ \\
\hline low-skilled & & 0.08 & 0.50 & 4.08 \\
$\quad$ young & 0.84 & 0.07 & 0.83 & 3.63 \\
middle-aged & 1.20 & 0.06 & 0.34 & 2.44 \\
$\quad$ old & 0.68 & & & \\
high-skilled & & 0.40 & 0.13 & 223.53 \\
$\quad$ young & 0.85 & 0.21 & 0.82 & 35.50 \\
middle-aged & 1.36 & 0.14 & 0.09 & 67.48 \\
$\quad$ old & 0.36 & & & \\
\hline
\end{tabular}

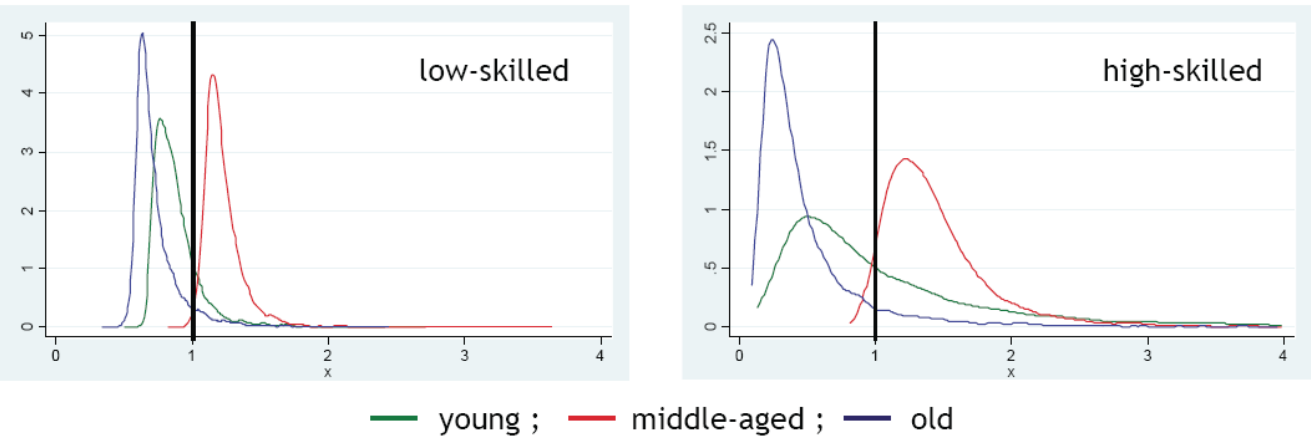

Contrasting results are found in the trade sector as shown in Table 16. For the low-skilled employees, the productivity/earnings ratio is very dispersed across the age groups. Likewise in services, the middle-aged workers are the most attractive, followed by juniors and seniors. Among the high-skilled, for all the age groups the distribution of the ratio converge closely around the mean and does not vary much. Again, the prime-age workers constitute the group whose majority has the ratio of productivity over cost higher than the sector average. They are followed by the older workers, whose distribution is well symmetric around the mean. 
Table 16: Ratio of relative productivity over relative wage (trade)

\begin{tabular}{|l|c|c|c|c|}
\hline & median & $\begin{array}{c}\text { median absolute } \\
\text { deviation }\end{array}$ & $\min$ & $\max$ \\
\hline low-skilled & & 0.06 & 0.37 & 3.67 \\
$\quad$ young & 0.64 & 0.10 & 0.95 & 2.97 \\
middle-aged & 1.44 & 0.01 & 0.05 & 0.26 \\
$\quad$ old & 0.12 & & & \\
high-skilled & & 0.10 & 0.14 & 29.40 \\
young & 0.80 & 0.05 & 0.67 & 2.75 \\
middle-aged & 1.06 & 0.14 & 0.23 & 3.02 \\
old & 0.95 & & & \\
\hline
\end{tabular}

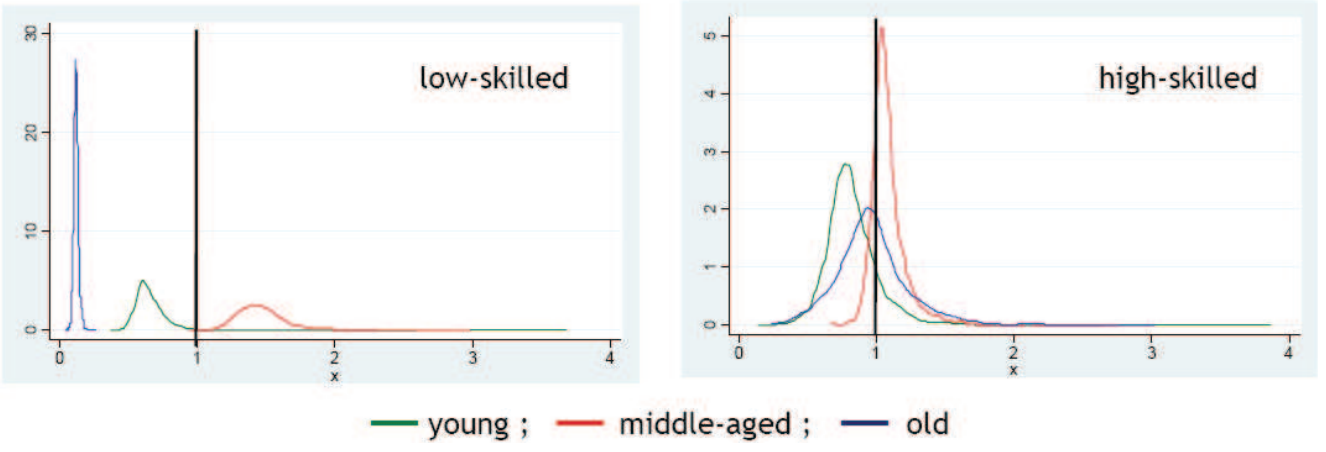

\section{Conclusions}

This paper revisits the question of the actual profile of marginal productivity across the age groups within the given workforce and its potential equality with profile of earnings. Using the French firm-level data, we estimated the parameters of the production function where the labour input, differentiated simultaneously by age and skills, takes a nested CES functional form. We controlled for the endogeneity bias according to the methodology by Levinsohn and Petrin (2003).

Among the main findings, workers of different age appear to be imperfect substitutes in production. The elasticity of substitution for workers of different age has been found considerably lower than implied by the additive functional form specification. Our results suggest that wages do not necessarily reflect the actual productivity. Consistent with study by Frank (1984) and Campbell and Kamlani (1997), the wage profile has been found less variable than productivity.

As far as the labour productivity is concerned, its profile across distinct age groups is likely to depend on the skill category. It has been found the lowest for the lowskilled older workers. Senior high-skilled employees in manufacturing and trade are 
the most productive group. The results for manufacturing sector show that the ageproductivity and age-earnings profiles are compatible with a deferred compensation system. It might indicate that the effort incentive problem has been regulated in practice by many firms by offering at the start of the career wages under the workers' marginal productivity and compensating this difference in the later periods. On the other hand, in services and in trade, we observe the combined relevance of specific human capital and deferred compensation.

Relative productivity over wage ratio, an important aspect for the employer, has been found sector-specific. In manufacturing, it is the highest for the young workers. In services and trade, the ratio is the highest for the middle-aged employees. This discrepancy between productivity and earnings can be a source of employment difficulties particularly for the older low-skilled workers.

\section{Appendix}

Table 17: Production function estimates for each sector, labour differentiated by age, sub-sector controls

\begin{tabular}{cllll}
\hline Parameters & \multicolumn{2}{c}{ Manufacturing } & \multicolumn{2}{c}{ Services } \\
\hline & NLLS & \multicolumn{1}{c}{ LP } & NLLS & \multicolumn{1}{c}{ LP } \\
\hline$\alpha$ & 0.222 & 0.284 & 0.241 & 0.189 \\
& $(0.005)^{* * *}$ & $(0.029)^{* * *}$ & $(0.006)^{* * *}$ & $(0.039)^{* * *}$ \\
$\beta$ & 0.811 & 0.679 & 0.710 & 0.642 \\
& $(0.008)^{* * *}$ & $(0.010)^{* * *}$ & $(0.011)^{* * *}$ & $(0.024)^{* * *}$ \\
$\delta_{y}$ & 0.325 & 0.293 & 0.275 & 0.299 \\
& $(0.019)^{* * *}$ & $(0.023)^{* * *}$ & $(0.026)^{* * *}$ & $(0.030)^{* * *}$ \\
$\delta_{m}$ & 0.450 & 0.508 & 0.427 & 0.425 \\
& $(0.027)^{* * *}$ & $(0.035)^{* * *}$ & $(0.048)^{* * *}$ & $(0.051)^{* * *}$ \\
$\delta_{0}$ & 0.224 & 0.198 & 0.298 & 0.276 \\
& & $(0.017)^{* * *}$ & & $(0.051)^{* * *}$ \\
$\rho_{a}$ & 0.345 & 0.188 & 0.935 & 0.759 \\
& $(0.075)^{* * *}$ & $(0.099)^{*}$ & $(0.213)^{* * *}$ & $(0.176)^{* * *}$ \\
sub-sector & & yes & yes & yes \\
controls & yes & & & \\
\hline No of obs. & 8185 & 8185 & 4498 & 4498 \\
\hline
\end{tabular}

Notes: Bootstrapped standard errors in parentheses.

*** Significant at $1 \%, * *$ significant at $5 \%, *$ significant at $10 \%$. 
Table 18: Production function estimates for each sector, labour differentiated by age and skills, sub-sector controls

\begin{tabular}{|c|c|c|c|c|c|c|}
\hline \multirow[t]{3}{*}{ Parameters } & \multirow{2}{*}{\multicolumn{2}{|c|}{$\begin{array}{c}\text { Manufacturing } \\
\text { no constraints }\end{array}$}} & \multicolumn{4}{|c|}{ Services } \\
\hline & & & \multicolumn{2}{|c|}{ no constraints } & \multicolumn{2}{|c|}{$\rho_{h}=0$} \\
\hline & NLLS & LP & NLLS & LP & NLLS & LP \\
\hline$\alpha$ & $\begin{array}{l}0.191 \\
(0.005)^{* * * *}\end{array}$ & $\begin{array}{l}0.283 \\
(0.041)^{* * *}\end{array}$ & $\begin{array}{l}0.218 \\
(0.006)^{* * *}\end{array}$ & $\begin{array}{l}0.167 \\
(0.042)^{* * *}\end{array}$ & $\begin{array}{l}0.219 \\
(0.006)^{* * *}\end{array}$ & $\begin{array}{l}0.167 \\
(0.042)^{* * *}\end{array}$ \\
\hline$\beta$ & $\begin{array}{l}0.827 \\
(0.008)^{* * *}\end{array}$ & $\begin{array}{l}0.714 \\
(0.009)^{* * *}\end{array}$ & $\begin{array}{l}0.733 \\
(0.011)^{* * *}\end{array}$ & $\begin{array}{l}0.668 \\
(0.025)^{* * *}\end{array}$ & $\begin{array}{l}0.724 \\
(0.011)^{* * *}\end{array}$ & $\begin{array}{l}0.660 \\
(0.025)^{* * *}\end{array}$ \\
\hline$\gamma$ & $\begin{array}{l}0.279 \\
(0.013)^{* * *}\end{array}$ & $\begin{array}{l}0.269 \\
(0.016)^{* * *}\end{array}$ & $\begin{array}{l}0.331 \\
(0.025)^{* * *}\end{array}$ & $\begin{array}{l}0.324 \\
(0.023)^{* * *}\end{array}$ & $\begin{array}{l}0.364 \\
(0.026)^{* * *}\end{array}$ & $\begin{array}{l}0.356 \\
(0.026)^{* * *}\end{array}$ \\
\hline $1-\gamma$ & 0.721 & $\begin{array}{l}0.730 \\
(0.016)^{* * *}\end{array}$ & 0.669 & $\begin{array}{l}0.675 \\
(0.023)^{* * *}\end{array}$ & 0.635 & $\begin{array}{l}0.643 \\
(0.026)^{* * * *}\end{array}$ \\
\hline$\delta_{l y}$ & $\begin{array}{l}0.441 \\
(0.033)^{* * * *}\end{array}$ & $\begin{array}{l}0.404 \\
(0.033)^{* * *}\end{array}$ & $\begin{array}{l}0.342 \\
(0.038)^{* * * *}\end{array}$ & $\begin{array}{l}0.371 \\
(0.034)^{* * * *}\end{array}$ & $\begin{array}{l}0.334 \\
(0.038)^{* * *}\end{array}$ & $\begin{array}{l}0.365 \\
(0.034)^{* * *}\end{array}$ \\
\hline$\delta_{l m}$ & $\begin{array}{l}0.420 \\
(0.046)^{* * *}\end{array}$ & $\begin{array}{l}0.465 \\
(0.052)^{* * *}\end{array}$ & $\begin{array}{l}0.435 \\
(0.071)^{* * *}\end{array}$ & $\begin{array}{l}0.451 \\
(0.062)^{* * * *}\end{array}$ & $\begin{array}{l}0.387 \\
(0.066)^{* * *}\end{array}$ & $\begin{array}{l}0.409 \\
(0.062)^{* * *}\end{array}$ \\
\hline$\delta_{l o}$ & 0.138 & $\begin{array}{l}0.131 \\
(0.029)^{* * *}\end{array}$ & 0.222 & $\begin{array}{l}0.177 \\
(0.055)^{* * *}\end{array}$ & 0.278 & $\begin{array}{l}0.226 \\
(0.060)^{* * *}\end{array}$ \\
\hline$\rho_{l}$ & $\begin{array}{l}0.437 \\
(0.117)^{* * *}\end{array}$ & $\begin{array}{l}0.323 \\
(0.118)^{* * *}\end{array}$ & $\begin{array}{l}0.653 \\
(0.234)^{* * *}\end{array}$ & $\begin{array}{l}0.473 \\
(0.160)^{* * *}\end{array}$ & $\begin{array}{l}0.814 \\
(0.248)^{* * *}\end{array}$ & $\begin{array}{l}0.608 \\
(0.172)^{* * *}\end{array}$ \\
\hline$\delta_{h y}$ & $\begin{array}{l}0.248 \\
(0.029)^{* * * *}\end{array}$ & $\begin{array}{l}0.246 \\
(0.032)^{* * *}\end{array}$ & $\begin{array}{l}0.211 \\
(0.041)^{* * *}\end{array}$ & $\begin{array}{l}0.214 \\
(0.067)^{* * *}\end{array}$ & $\begin{array}{l}0.132 \\
(0.028)^{* * *}\end{array}$ & $\begin{array}{l}0.144 \\
(0.035)^{* * *}\end{array}$ \\
\hline$\delta_{h m}$ & $\begin{array}{l}0.403 \\
(0.037)^{* * *}\end{array}$ & $\begin{array}{l}0.435 \\
(0.044)^{* * *}\end{array}$ & $\begin{array}{l}0.391 \\
(0.067)^{* * *}\end{array}$ & $\begin{array}{l}0.361 \\
(0.091)^{* * *}\end{array}$ & $\begin{array}{l}0.696 \\
(0.045)^{* * *}\end{array}$ & $\begin{array}{l}0.664 \\
(0.054)^{* * *}\end{array}$ \\
\hline$\delta_{h o}$ & 0.348 & $\begin{array}{l}0.318 \\
(0.027)^{* * *}\end{array}$ & 0.398 & $\begin{array}{l}0.424 \\
(0.132)^{* * *}\end{array}$ & 0.172 & $\begin{array}{l}0.191 \\
(0.037)^{* * *}\end{array}$ \\
\hline$\rho_{h}$ & $\begin{array}{l}0.726 \\
(0.124)^{* * *}\end{array}$ & $\begin{array}{l}0.581 \\
(0.138)^{* * *}\end{array}$ & $\begin{array}{l}1.009 \\
(0.288)^{* * * *}\end{array}$ & $\begin{array}{l}0.984 \\
(3.484)\end{array}$ & 0 & 0 \\
\hline $\begin{array}{l}\text { sub-sector } \\
\text { controls }\end{array}$ & yes & yes & yes & yes & yes & yes \\
\hline No of obs. & 8185 & 8185 & 4498 & 4498 & 3309 & 3309 \\
\hline
\end{tabular}

Notes: Bootstrapped standard errors in parentheses.

*** Significant at $1 \%,{ }^{* *}$ significant at $5 \%, *$ significant at $10 \%$. 


\section{References}

Arrow, K., Chenery, H., Minhas, B., and Solow, R. (1961). Capital-labor substitution and economic efficiency. The Review of Economics and Statistics, 43(3):225-250.

Aubert, P. and Crépon, B. (2003). Âge, salaire et productivité. Documents de travail G2003/06, INstitut National de la Statistique et des Études Économiques.

Becker, G. (1975). Human Capital. National Bureau of Economic Research.

Becker, G. and Stigler, G. (1974). Law enforcement, malfeasance and the compensation of enforcers. Journal of Legal Studies, 3:1-18.

Bulow, J. and Summers, L. H. (1986). A theory of dual labor markets with application to industrial policy, discrimination and keynesian unemployment. Journal of Labor Economics, 4:376-414.

Campbell, C. M. and Kamlani, K. S. (1997). The reasons for wage rigidity: Evidence from a survey of firms. The Quarterly Journal of Economics.

Colonia-Willner, R. (1998). Practical intelligence at work: relationship between aging and cognitive efficiency among managers in a bank environment. Psychology and Aging, 13 (1):45-57.

Crépon, B., Deniau, N., and Pérez-Duarte, S. (2002). Wages, productivity, and worker characteristics: A french perspective. Technical report.

Daveri, F. and Maliranta, M. (2006). Age, technology and labour costs. Discussion Papers 1010, The Research Institute of the Finnish Economy.

Frank, R. (1984). Are workers paid their marginal products? The American Economic Review, 74 (4):549-571.

Grund, G. and Westergård-Nielsen, N. (2005). Age structure of the workforce and firm performance. Discussion Papers 1816, Institute for the Study of Labor.

Guest, R. and Shacklock, K. (2005). The impending shift to an older mix of workers: Perspectives from the management and economics literatures. International Journal of Organisational Behaviour, 10(3):713-728.

Hashimoto, M. (1981). Firm-specific human capital as a shared investment. The American Economic Review, 71(3):475-482.

Hellerstein, J. and Neumark, D. (2006). Production function and wage equation estimation with heterogeneous labor: Evidence from a new matched employeremployee data set. Technical report, NBER Working Paper. 
Hellerstein, J. K., Neumark, D., and Troske, K. R. (1999). Wages, productivity, and worker characteristics: Evidence from plant-level production functions and wage equations. Journal of Labor Economics, 17(3).

Hutchens, R. (1986). Delayed payment contracts and a firm's propensity to hire older workers. Journal of Labor Economics, 4:439 - 57.

Kremer, M. and Thomson, J. (1998). Why isn't convergence instantaneous? young workers, old workers, and gradual adjustment. Journal of Economic Growth, 3:528 .

Lam, D. (1989). Population growth, age structure, and age-specific productivity. does a uniform age distribution minimize lifetime wages? Journal of Population Economics, 2:189-210.

Lazear, E. P. (1979). Why is there mandatory retirement? Journal of Political Economy, 87(6):1261-1284.

Lazear, E. P. (1981). Agency, earnings profiles, productivity, and hours restrictions. The American Economic Review, 71(4):606-620.

Lengermann, P. A. (2002). Is it who you are, where you work, or with whom you work? reasessing the relationship between skill segregation and wage inequality. Technical Paper TP-2002-10, U.S. Census Bureau.

Levinsohn, J. and Petrin, A. (2003). Estimating production functions using inputs to control for unobservables. Review of Economic Studies, 70:317-341.

Loewenstein, G. and Sicherman, N. (1991). Do workers prefer increasing wage profiles? Journal of Labor Economics, 9 (1):67-84.

Marschak, J. and Andrews, W. H. (1944). Rndom simultaneous equations and the theory of production. Econometrica, 12 (3-4):143-205.

Maurer, T. (2001). Career-relevant learning and development, worker age, and beliefs about self-efficacy for development. Journal of Management, 27 (2).

Mincer, J. (1974). Schooling, Experience and Earnings. NY: Columbia University Press.

Parzen, E. (1962). On estimation of a probability density function and mode. The Annals of Mathematical Statistics, 33(3):1065-1076.

Remery, C., Henkens, K., Schippers, J., and Ekamper, P. (2003). Managing an ageing workforce and a tight labour market. Population Research and Policy Review, $22(1): 21-40$. 
Shapiro, C. and Stiglitz, J. (1984). Equilibrium unemployment as a worker discipline device. American Economics Review, 74:433-444.

Skirbekk, V. (2003). Age and individual productivity: A literature survey. MPIDR Working Paper 2003-028, Max Planck Institute for Demographic Research, Rostock, Germany.

Thesmar, D. and Thoenig, M. (2000). Creative destruction and firm organization choice. The Quarterly Journal of Economics, 115(4):1201-1237.

Yellen, J. (1984). Efficiency wage models of unemployment. American Economic Review, 74:200-208. 